This item was submitted to Loughborough's Research Repository by the author.

Items in Figshare are protected by copyright, with all rights reserved, unless otherwise indicated.

\title{
Mechanisms for preventing rising damp in new building infrastructure
}

PLEASE CITE THE PUBLISHED VERSION

https://doi.org/10.1108/IJBPA-06-2018-0048

\section{PUBLISHER}

(c) Emerald Publishing Limited

\section{VERSION}

AM (Accepted Manuscript)

\section{PUBLISHER STATEMENT}

This work is made available according to the conditions of the Creative Commons Attribution-NonCommercialNoDerivatives 4.0 International (CC BY-NC-ND 4.0) licence. Full details of this licence are available at: https://creativecommons.org/licenses/by-nc-nd/4.0/

\section{LICENCE}

CC BY-NC-ND 4.0

\section{REPOSITORY RECORD}

Agyekum, K., Karen B. Blay, and Alex Opoku. 2019. "Mechanisms for Preventing Rising Damp in New Building Infrastructure". figshare. https://hdl.handle.net/2134/34781. 


\title{
MECHANISMS FOR PREVENTING RISING DAMP IN NEW BUILDING
} INFRASTRUCTURE

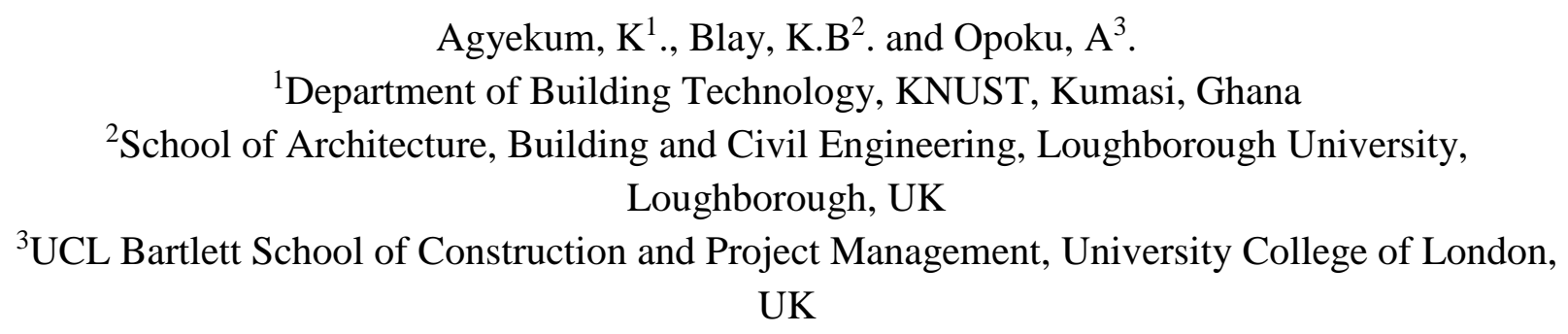

\begin{abstract}
Purpose: Capillary rise of water in buildings has been an issue of concern among past and present researchers. Despite the research efforts devoted to the proper elimination of the problem in masonry construction, it still remains a challenge that needs to be addressed. This study explores treatment mechanisms that can be used to prevent rising damp in new building infrastructure.

Methodology: Fourteen test walls are constructed, conditioned, subjected to various treatments, and monitored for four years. The treatments applied to the walls include the use of polyethylene damp proof courses, damp proof coatings, and dense concrete bases. The walls are then monitored with reference to the two climate seasons in Ghana.
\end{abstract}

Findings: The results highlights that rising damp is present, as suggested by the constant increase and decrease in the height of the water levels in the walls during the rainy and dry seasons respectively. The findings further reveal that within the four-year period, the walls treated with the damp proof coatings, together with those with the dense concrete bases performed better than those treated with the polyethylene damp proof courses.

Limitations: The economic and commercial impact of these preventive mechanisms were not considered in this study. A future research can be directed at these issues.

Practical implication: The proposed treatment mechanisms highlights the effectiveness of some treatments applied to walls to prevent the capillary rise of water from the ground into the superstructure.

Social implications: Building regulations, especially in Ghana and other tropical settings should be amended to include ways to prevent rising damp phenomena by including effective methods against rising damp during the building design or construction.

Originality/Value: Series of studies worldwide have been conducted in laboratories to simulate the capillary rise of water in walls of buildings. This is among the few studies that look at how water rises from actual ground conditions into the walls of buildings.

Keywords: Building infrastructure, Rising damp, Damp Proof Courses, Damp Proof Coatings, Test Wall, dense concrete

\section{Paper type: Research paper}




\section{Introduction}

Building infrastructure is a bedrock for development in any country. The provision of adequate infrastructure encourages economic growth, ensures poverty reduction, and improves on the delivery of health and other services (Mitullah et al., 2016; World Bank, 2014; Wantchekon, 2014). For many years now, Africa has enjoyed significant social and economic progress (African Development Bank, 2018). However, the deficit in infrastructure has demoralized all the efforts towards achieving sustainable development and structural transformation. According to the African Development Bank, AfDB, (2013), though Africa still has a massive infrastructure need, it invests only $4 \%$ of its gross domestic product in infrastructure, as compared to a developed nation like China, which invests $14 \%$ of its GDP. A current survey undertaken by Afrobarometer and reported on by Mitullah et al. (2016) shows that infrastructure remains a major challenge in Africa. To bridge the infrastructure deficit, there is the urgency to provide buildings, roads, railways and ports, information and communication technology, energy facilities, health facilities, and the management of water (Foster, 2008).

Key to the provision of infrastructure by governments in Africa is the provision of adequate housing for its people. The rapid growth in population and urbanization, especially in Africa has resulted in sub-standard housing conditions, overcrowding of households, inadequate and unreliable infrastructure and services (Tibaijuka, 2009). Ghana, like many other developing countries, has been facing an acute shortage of housing for many years now. According to the Ghana Statistical Service, GSS, (2014), there are about 5.8 million dwelling units in Ghana. Of these units, less than half can be classified as houses (GSS, 2014). With the country's population increasing at a rate of 2.7 per annum, the increase in housing stock is unable to keep pace and the situation is worsening (Adinkrah-Appiah et al., 2015). This notwithstanding, the few houses available to the people have not been given proper maintenance attention, and are being affected by series of defects. One of the key defects associated with housing in Ghana is dampness (Agyekum et al., 2013). The common type of dampness found among such buildings is rising damp (Agyekum et al., 2013).

Rising damp is a widespread phenomenon and has been a major cause of decay of masonry materials for many years now (Franzoni et al., 2013). It occurs 'when groundwater flows into the base of a construction and is allowed to rise through the pore structure' (Rirsch and Zhang, 2010, p. 1815). Rirsch et al. (2011) further indicated that rising damp describes the movement of moisture upwards through permeable building materials by capillary action. When serious rising damp occurs in a building, that building becomes inhospitable due to mould growth, paint blistering, plaster crumbling and wall paper separation (Rirsch et al., 2011). According to Franzoni et al. (2014), it is one of the most significant phenomena that leads to the decay of ancient buildings, as well as modern porous building materials, probably because it speeds up all degradation processes in such buildings. 
In Ghana, the problem is widespread among buildings to such an extent that more than one out of every ten residential buildings is affected by it. There have been series of studies dedicated to studying the problem and its harmful effects (Falchi et al., 2018; Franzoni, 2014; Franzoni et al., 2013; Franzoni and Bandini, 2012; Franzoni and Sassoni, 2011; Rirsch and Zhang, 2010). These studies have been accompanied by several treatment methods and mechanisms. In existing buildings, techniques such as mechanical interruptions, chemical injection, Knapen Siphons, wall base ventilation, thermal methods, active electro-osmosis, passive electro-osmosis, electro-kinesis and the likes exist on the market to stop rising damp in walls (Lubelli et al., 2018; Franzoni, 2018; Vanhellemont et al., 2018; Melada et al., 2018; van Hees et al., 2018; Torres, 2018; Lubelli et al., 2013). Despite the huge applications of these products and techniques, scientific literature on this subject is still scarce. The few publications on the treatment of rising damp in existing buildings are limited to the study of the effectiveness of one or few products in the laboratory or on the field (Lubelli et al., 2013).

Lubelli et al. (2013) further stated that the lack of homogeneity of data, because of the different boundary conditions and test methods makes it difficult to draw general conclusions on the behavior of different classes of products. Aside these issues, there are also complications arising from the fact that producers of some so-called damp remediation chemicals are unwilling to provide clear and extensive information on their products. According to Franzoni (2014), rising damp is persistent, and its removal from both old and modern types of buildings has become very challenging. This study was conducted to explore mechanisms that can be used to prevent rising damp in new buildings. Various researchers have contributed their quota in this area. Several books regarding the description of the phenomenon in building materials like concrete, bricks, wood and the likes have been published. However, this research forms part of the few studies that looks at the on-site (actual ground) modelling of the problem of rising damp in a frequently used building material in Ghana, i.e. Sandcrete blocks.

\subsection{The use of sandcrete blocks for building in Ghana}

Sandcrete blocks are walling units which are made from coarse natural sand or crushed stone dust mixed with cement and water and pressed to shape (Baiden and Tuuli, 2004). The blocks on setting and hardening attain sufficient strength to be used as walling units as specified by BSI (1974, 1975).

Per the classifications of BS 2028, blocks have been classified into three types to include: Type A (Dense aggregate blocks); Type B (Lightweight aggregate blocks for load bearing walls); and Type C (Lightweight aggregate blocks for non-load bearing partitions). Baiden and Tuuli (2004) indicated that sandcrete blocks are widely used as walling units in Ghana. This fact was confirmed in the 2010 population and housing census which revealed that more than $50 \%$ of buildings in Ghana had the walling units in sandcrete blocks. As a result of its widespread use, most commercial factories have been manufactured to produce such blocks. However, the properties of the blocks, and especially, the quality, differs from one manufacturer to the other due to the different methods used in the production (Baiden and Tuuli, 2004). 
A sandcrete block qualifies as a walling material if it exhibits high compressive strength, low shrinkage, low moisture movement, low thermal movement and denseness and durability (Baiden and Tuuli, 2004), which can only be achieved through its adherence to BS 2028 recommendations on mix ratio, curing and quality of constituent materials. This notwithstanding, one can easily lose the quality of sandcrete blocks if proper attention is not given to the quality of constituent materials, batching of the aggregates, mixing of the constituent materials, method of production, curing, transportation and storage, mix ratio and water content (Baiden and Tuuli, 2004).

In Ghana, sandcrete blocks come in different sizes and forms, with the length, width or height greater than that specified for a brick. The blocks are produced as solid or hollow in Ghana. The blocks are used for single leaf wall construction, where the blocks are laid to overlap in one or more directions and set solidly in mortar (Baiden and Tuuli, 2004). The blocks are also laid in running or stretcher bonds in which the units of successive courses overlap half their length, and the joints in between the blocks are usually filled with cement sand mortar (Baiden and Tuuli, 2004).

Since this is the most widely used walling material in Ghana, and because previous studies had revealed that buildings constructed with sandcrete blocks were severely affected by rising damp (Agyekum et al., 2014; Agyekum et al., 2013), the current study was conducted using sandcrete blocks.

\subsection{Research methodology}

The study sought to explore mechanisms that can be used to prevent rising damp in new building infrastructure. This study is experimental in nature, and involved the construction of fourteen Test walls (prototype models). The first set of walls (seven in number) were constructed with Standard Manufactured Sandcrete Blocks (SB) and the second set of walls (also seven in number) were constructed with Commercially Manufactured Sandcrete Blocks (CB). The constructed test models were further conditioned, treated and monitored over a period of 4 years. In a previous paper (Agyekum et al., 2016), the test walls built were monitored for 365 days, and subsequently reported on. The findings revealed that the height of rise of moisture within the walls varied with respect to the seasonal changes in Ghana. In this current paper, the walls have been monitored for an additional 3 years (making four years in total) and further findings obtained will be reported. The methodology used has been divided into four subsections to include: the materials; location of test walls and wall constructions; mechanisms applied to prevent rising damp in the test walls; and monitoring the effectiveness of the applied mechanisms.

\subsection{Materials}

\subsubsection{Materials for manufacturing of sandcrete blocks and mortar for rendering}

The standard and commercial sandcrete blocks (SBs and CBs) were manufactured with sharp sand, cement and water (Lewis, 1959). The sand used met the requirements of BS 1200 (1976). The 
cement used for the production of the sandcrete blocks, and rendering was Ordinary Portland cement from Ghana Cement Works Limited, and it conformed to the Ghana Standards Board Specification No. A2 (1995). Fresh, colourless, odourless and tasteless potable water free from organic matter and which conformed to the requirements as stated in BS 1200 (1976) was used in mixing the materials. Tests carried out at the West African Building Research Institute has confirmed that the strength of sandcrete blocks like other cement products increase with decreasing water cement ratio. As a result of this, the addition of the water to the mixture was based on the standard specification of 0.45 water to cement ratio. Anything beyond this could have contributed to prolonged setting time, and a reduction in the relative strength of the sandcrete block (Agyekum et al., 2016).

Both the standard and commercial sandcrete blocks were manufactured in an approved blockmaking vibrating machine which conformed to BS 2028 (1975). Both the SBs and CBs were of sizes $115 \mathrm{~mm} \times 225 \mathrm{~mm} \times 460 \mathrm{~mm}$. The SBs were manufactured with a standard mix proportion of 1:6 (i.e. one part by volume of cement to 6 parts by volume of coarse sand) (Lewis, 1959). A mix proportion of 1:8 was used to manufacture the CBs (Agyekum et al., 2016). This mix proportion was based on that used on many Ghanaian construction sites. Such mixes are also used by commercial block manufacturing firms on the Ghanaian market. These two kinds of sandcrete blocks were used for the following reasons: i) to determine whether the issue of quality control contributes to the problem of moisture rise in walls constructed with such materials (Agyekum et al., 2016); and ii) to determine whether differences in the mix proportions of the blocks contribute to the susceptibility of the materials to damp penetration (Agyekum et al., 2016). All the blocks manufactured were of the load bearing capacities, thus meeting the requirements of BS 2028 (1975). To determine the quality of the sandcrete blocks manufactured, their bulk densities, water absorption capacities and compressive strengths were determined after curing for 28 days.

\subsubsection{Materials (mechanisms) for the treatment of the walls}

Polyethylene damp proof courses (dpcs), damp proof coatings labelled as 'A' and ' $\mathrm{B}$ ', and dense concrete bases were used as treatments for the walls against the capillary rise of water. The polyethylene damp proof courses used were of thicknesses $0.15 \mathrm{~mm}, 0.13 \mathrm{~mm}$ and $0.12 \mathrm{~mm}$, and were manufactured to the requirements of BS 6515 (1984). These thicknesses were chosen based on that readily available on the Ghanaian market. Damp proof coating ' $\mathrm{B}$ ' is an elastic isolation material modified with special chemicals, which provide excellent water insulation. It is liquid plastic, elastic when dry, flexible, strong, endures mechanical blows and highly impermeable to water. It is applied to all walls which require water insulation, ground, roof, terrace, etc. The damp proof coating 'A' is a two-pack, modified epoxy paint cured by polyamid. Pack A: BB 4301 3,2L is 8 parts in volume and Pack B: SB 5733 0.4L is one part in volume. The product is applied over carbon steel, concrete, wood, aluminium/galvanized surfaces, which are to be buried or immersed in salt or fresh water. It is also applied to damp proof walls affected by moisture and rising dampness, both internally and externally (Agyekum et al., 2016). The last set of treatment used 
consisted of a dense concrete wall. The density of the concrete used was 2,438 $\mathrm{kg} / \mathrm{m}^{3}$ (1:3:6 concrete mix) after a 28-day curing state. This density fell within the range of 2,200-2,600 kg/m regarded as density of normal weight concrete (Neville, 1999).

\subsection{Location of test walls and wall constructions}

Burkinshaw (2012) indicated that the biggest variable in a test of this kind is the ground moisture condition. The experimental test walls were constructed at Deduako, a suburb of Oforikrom SubMetro which falls under the Kumasi Metropolitan Assembly in the Ashanti Region of Ghana. The swampy nature of the site made it a suitable location for this study (Agyekum et al., 2016).

The site is generally underlain by granite which is a later intrusion into the lower birimian rocks. The soil type found in this location is mostly residual in nature with covering of weathered argellateous phyllite from the country rock (Kesse, 1985). The site is located near a river and the water table of the surrounding is high, making it suitable for a true rising damp scenario to be replicated.

Fourteen masonry test walls of dimensions $2.1 \mathrm{~m}$ high by $2.0 \mathrm{~m}$ long were constructed at the location. The walls were not erected under sheds in order to ensure their complete exposure to the inclement weather. The construction of the fourteen test walls began on $1^{\text {st }}$ July 2014 and ended on $24^{\text {th }}$ July 2014.

The first set of walls, which consisted of seven free standing walls were constructed of the SBs, whilst the second set of walls, also made up of seven free standing walls were constructed of the CBs. The CB construction was used to replicate to an extent the kind of blockwork construction commonly adopted during the construction of residential buildings in Ghana (Agyekum et al., 2016).

The first six walls for each type of sandcrete blocks (both SB and CB) had the same thicknesses, and consisted of several courses laid in stretching bonds to heights of $2.1 \mathrm{~m}$ and lengths of $2.0 \mathrm{~m}$ in a single width. The various courses were bonded with cement and sand mortar mix proportion of 1:4 as specified by the National Building Regulation of Ghana (Section 32(2) (1989) (Lewis, 1959). All the block walls were finished with $13 \mathrm{~mm}$ thick sand and cement render (1:5), applied in several layers (Agyekum et al., 2016).

The seventh test walls for the SB and CB comprised of mass concrete bases of heights $900 \mathrm{~mm}$ above ground, and each with a mix ratio of 1:3:6. The top levels above the $900 \mathrm{~mm}$ concrete bases were completed with sandcrete blocks up to the heights of $2.1 \mathrm{~m}$ each (Agyekum et al., 2016). 


\subsection{Mechanisms applied to prevent rising damp in the test walls}

Fig 1 Photograph of test walls (extreme left are those constructed with SBs and extreme right are those constructed with CBs) (Source: Agyekum et al., 2016)

Several mechanisms were identified in literature and through personal interactions with construction professionals. The various mechanisms applied to prevent rising damp in the walls are presented in Table 1.

Figure 2 shows how the polyethylene dpcs for the test walls 1, 2 and 3 (for both SBs and CBs) were laid. Figure 3 also shows the complete set of walls with the different polyethylene dpcs in place as described in Table 1.

Table 1. Summary of mechanisms applied to prevent rising damp in the walls

\begin{tabular}{|l|l|l|}
\hline \multicolumn{1}{|c|}{ CODE } & \multicolumn{1}{|c|}{ EXPLANATION } & \multicolumn{1}{|c|}{ TYPE OF MECHANISM } \\
\hline SB1 \& CB1 & $\begin{array}{l}\text { Standard and commercially manufactured } \\
\text { sandcrete block walls with 0.15 mm thick damp } \\
\text { proof course (dpc). }\end{array}$ & $\begin{array}{l}\text { Polyethylene dpc with a } \\
\text { thickness of 0.15 mm. }\end{array}$ \\
\hline SB2 \&CB2 & $\begin{array}{l}\text { Standard and commercially manufactured } \\
\text { sandcrete block walls with 0.13 mm thick dpc. }\end{array}$ & $\begin{array}{l}\text { Polyethylene dpc with a } \\
\text { thickness of 0.13 mm. }\end{array}$ \\
\hline SB3 \& CB3 & $\begin{array}{l}\text { Standard and commercially manufactured } \\
\text { sandcrete block walls with 0.12 mm thick dpc. }\end{array}$ & $\begin{array}{l}\text { Polyethylene dpc with a } \\
\text { thickness of 0.12 mm. }\end{array}$ \\
\hline SB4 \& CB4 & $\begin{array}{l}\text { Standard and commercially manufactured } \\
\text { sandcrete block walls with damp proof coating } \\
\text { 'A' }\end{array}$ & $\begin{array}{l}\text { Damp proof coating 'A' applied } \\
\text { to walls. }\end{array}$ \\
\hline SB5 \& CB5 & $\begin{array}{l}\text { Standard and commercially manufactured } \\
\text { sandcrete block walls with damp proof coating } \\
\text { 'B'. }\end{array}$ & $\begin{array}{l}\text { Damp-proof coating 'B' applied } \\
\text { to walls. }\end{array}$ \\
\hline SB6 \& CB6 & $\begin{array}{l}\text { Standard and commercially manufactured } \\
\text { sandcrete block walls with no treatment } \\
\text { (control test walls). }\end{array}$ & $\begin{array}{l}\text { Control test walls (No treatment } \\
\text { applied). }\end{array}$ \\
\hline SB7 \& CB7 & $\begin{array}{l}\text { Standard and commercially manufactured } \\
\text { sandcrete block walls with concrete bases. }\end{array}$ & $\begin{array}{l}\text { 150 mm thick concrete bases to } \\
\text { heights of 900 mm each. }\end{array}$ \\
\hline
\end{tabular}



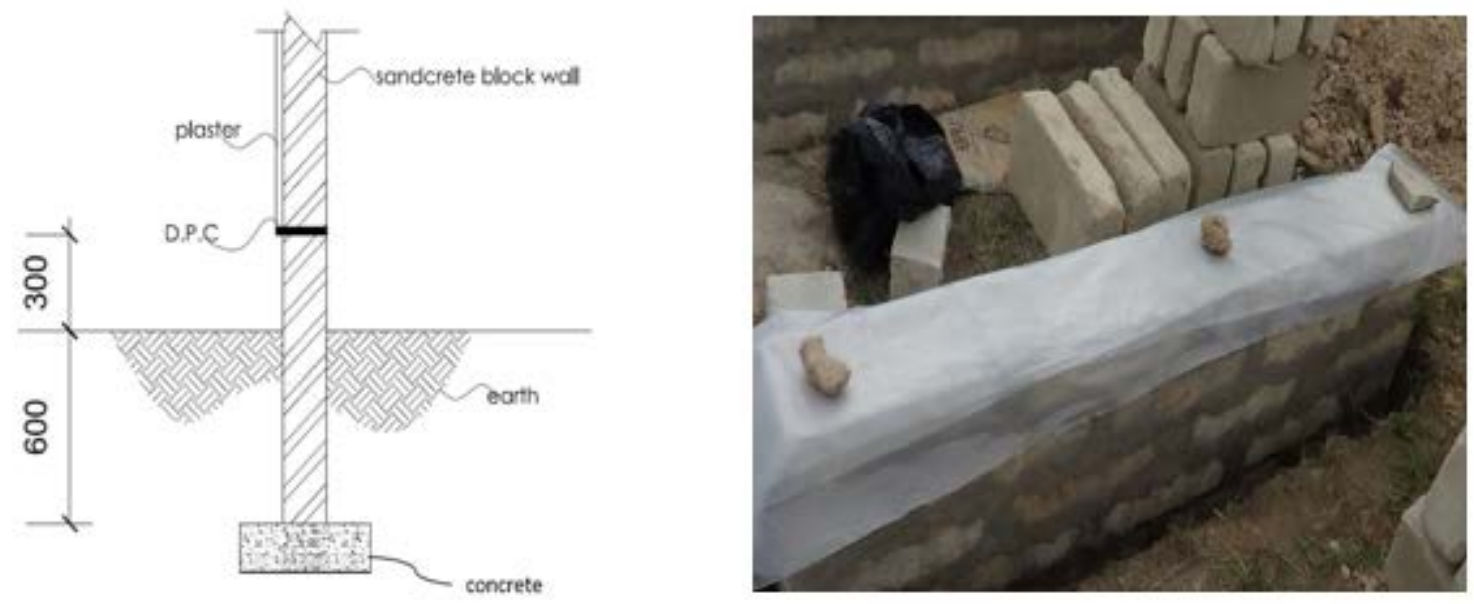

249 Fig 2 (a) Schematic diagram of the position of the dpc (b) Photograph showing how the dpc was 250 laid (Source: Agyekum et al., 2016)

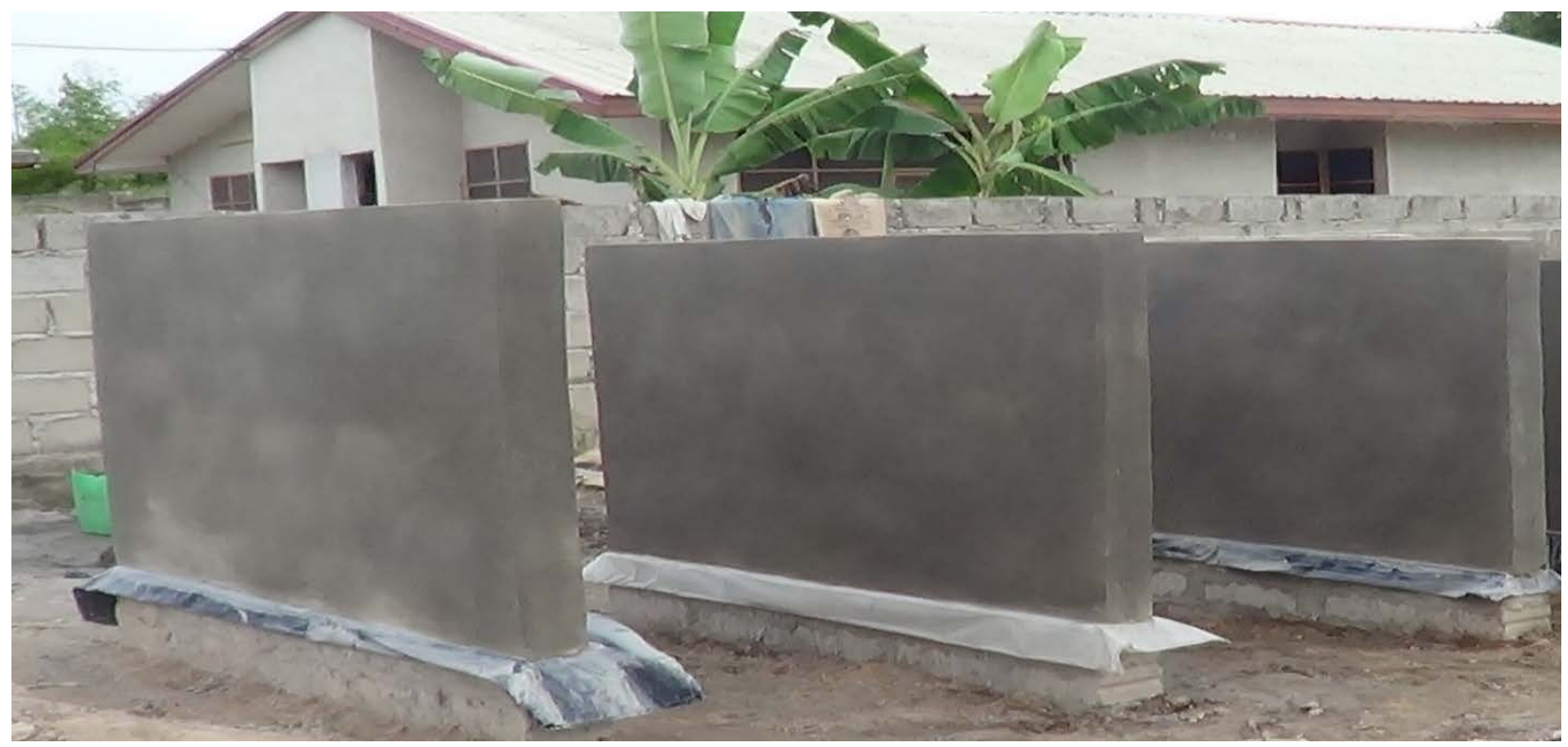

252 Fig 3 Photograph of test walls after the dpcs were laid

254 The damp proof coatings were also applied to the fourth sets of test walls. During the application 255 of damp proof coating 'A', the wall surfaces were thoroughly cleaned and dried (Figure 4). The 256 soil of the adjoining walls was excavated about 3 feet $(900 \mathrm{~mm})$ deep. A catalyzer was mixed with 257 the epoxy paint, stirred and left to stand for 30 minutes. The catalyzer was part of the product as 
specified by the manufacturer. The damp proof coating ' $A$ ' was then applied on the perimeters of the walls, 3 feet from the soil and allowed to dry (Agyekum et al., 2016).

260 Similar preparations as done for the application of damp proof coating ' $A$ ' was done for the damp proof coating ' $\mathrm{B}$ '. Before its application the product was thinned with water in the rate of $40 \%$ and applied to the walls. After drying first coat, the second and third coats were applied without dilution and allowed to stand for 48 hours after which the walls became completely dried (Agyekum et al., 2016). Figures 5 and 6 show the test walls after the applications of the damp proof coatings.

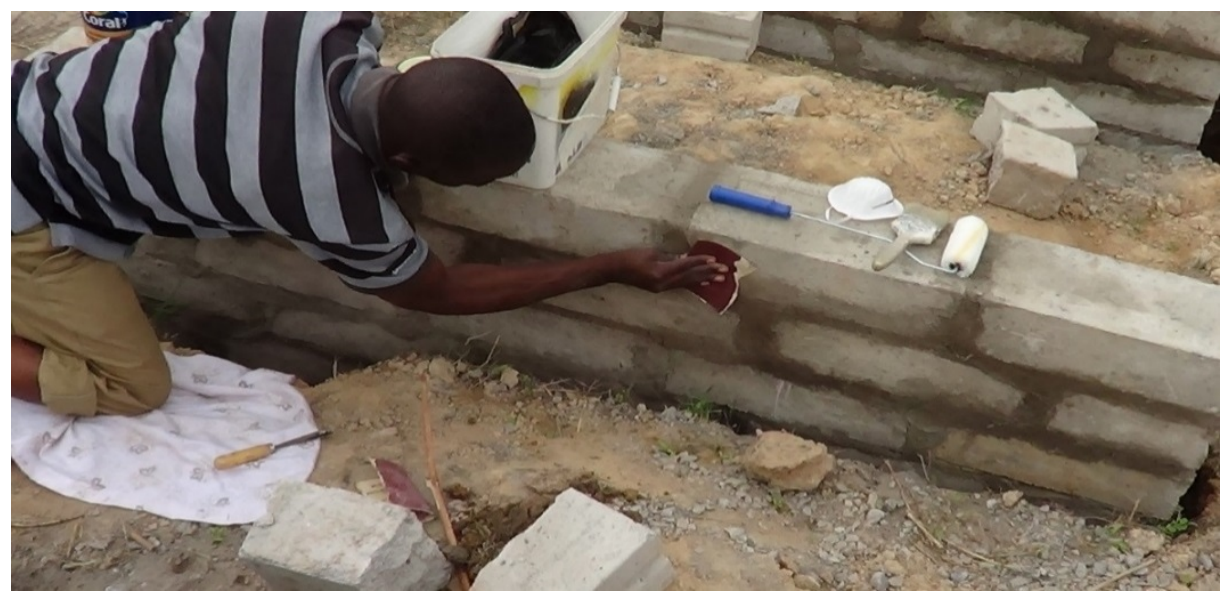

Fig 4 Photograph showing the preparation of the wall surfaces
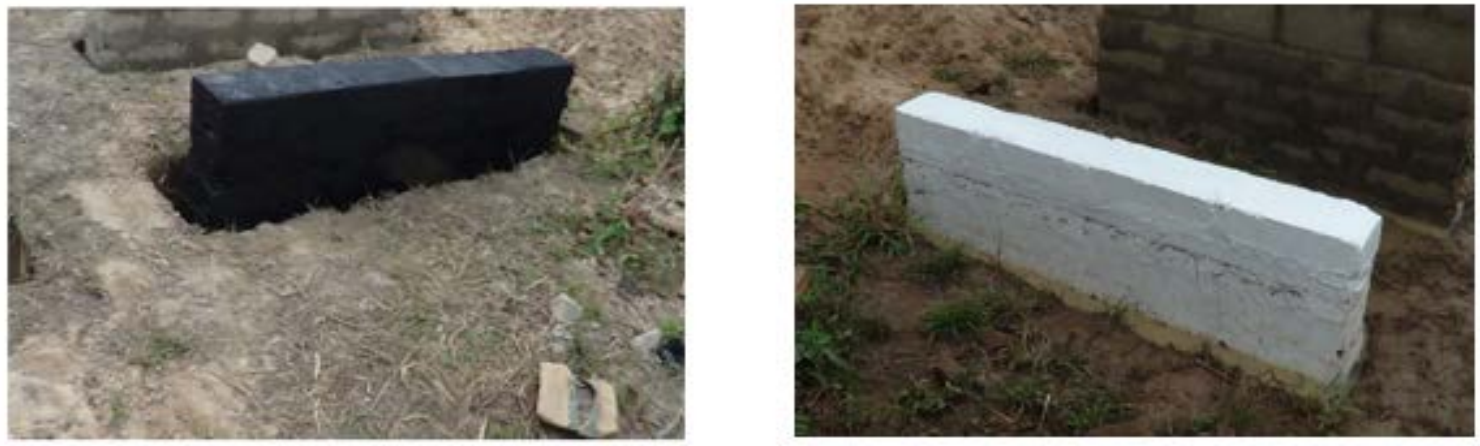

282 Fig 5 Photographs of the walls after the damp proof coatings 'A' (left) and 'B' (right) were 283 applied 


\section{Fig 6 Photograph of test walls after they were treated with the damp proof coatings}

Test walls 6 for each of the different wall constructions (SBs and CBs) were left untreated to serve as controls. These walls were untreated to have reference walls against which to evaluate the effectiveness of the treatments applied to the other walls. Figure 7 shows the schematic diagrams of the test walls 6 . For Test walls 7 of the two different constructions, concrete bases were erected to heights of $900 \mathrm{~mm}$ above ground levels. Figure 8 is a schematic diagram of how the test walls 7 were constructed (Agyekum et al., 2016).

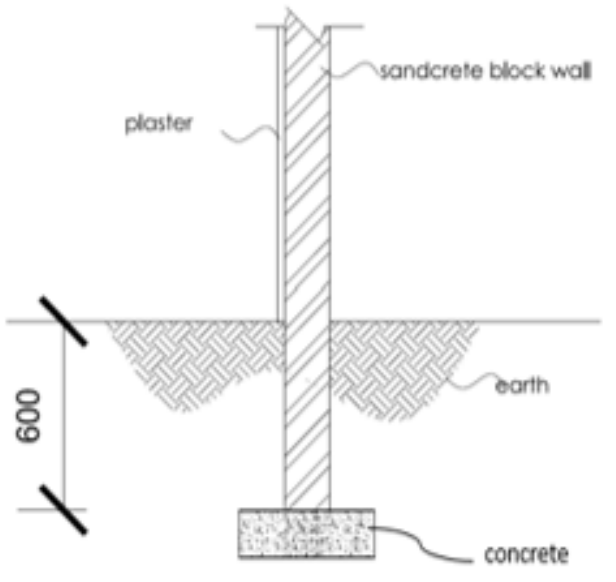

305

306

307

308

309

310

311

312
Fig 7. A schematic diagram of control test walls constructed without any treatment

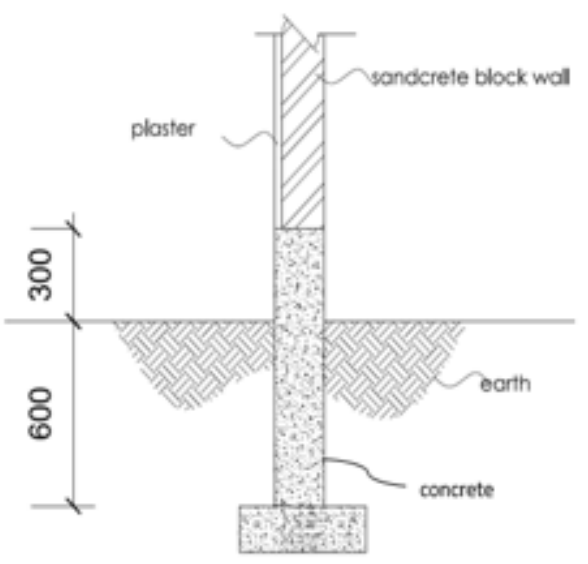

Fig 8. A schematic diagram of test walls 7 with dense concrete base

\subsection{Monitoring the effectiveness of the applied mechanisms}

The constructed test walls were left for five months after which the effectiveness of the applied mechanisms were monitored. In a similar study conducted by Rirsch and Zhang (2010), the erected 
walls were allowed to reach a steady level of saturation a little over five months before the first measurement was taken. As part of the monitoring, the level achieved by the damp front was of great importance. This was necessary to tell whether water had risen in the bases of the walls, and also to determine whether the mechanisms were performing very well. Moisture contents were measured on the walls using the PCE MMK1 moisture meter with deep probes, and the heights achieved by the damp front was visually measured with a steel tape.

Prior to the measurement of the height achieved by the damp front, it was very necessary to determine whether the bases of the walls had been soaked with water, and that the water seen was not just at the surfaces of the walls. The PCE MMK1 moisture meter assisted in carrying out this task. Data on the level achieved by the damp front was recorded in two seasons, (i.e. the rainy and the dry seasons) for four years. This was very important to be able to monitor the effect of the seasonal changes on the capillary rise of water in the walls. The primary use of the moisture meter in this study was not to measure the moisture contents of the individual walls. It was used to determine whether the bases of the walls were actually wet and that the heights achieved by the damp front was not only a matter of surface water.

For the PCE-MMK1 universal moisture meter, maximum moisture content for masonry materials like cement mortar are recorded at 3.0\%. Moisture content readings were interpreted as follows (Agyekum et al., 2014): The wall is considered a very wet zone where the moisture contents recorded are greater than 2.8\%; A moist condition is recorded where the moisture content ranges between $1.5 \%$ and $2.8 \%$; and a dry condition or level of dampness is recorded where the moisture content is less than $1.5 \%$.

The distribution of the moisture contents (recorded using the moisture meter) along the lengths of the walls at the damp front are shown in Figure 9. Test walls SB 6 and CB 6 were used as the test cases. For the purposes of this study, the researchers were only interested in the level achieved by the damp front, and so only the results on the height of reach of the water in the walls have been presented.

Figure 9 shows the moisture meter readings on the surfaces of the walls. The percentage moisture contents circled showed the problematic areas. Mortar samples were obtained from these areas to determine the level of wetness at the various depths.

As already described, the walls were constructed with sandcrete blocks, and the joints between the blocks were filled with $150 \mathrm{~mm}$ thick mortar. Mortar samples were selected because it is the dominant path through which damp rises in walls of buildings (Burkinshaw and Parrett, 2004). The equipment used to obtain the mortar samples were cordless drill bits, sharp tungsten carbide drill bits, $35 \mathrm{~mm}$ camera film cases for holding the samples, plastic resealable sample bags, sharp $65 \mathrm{~mm}$ bolster and small piece of card for collecting dust. The mortar samples were obtained at depths of $0-25 \mathrm{~mm}, 25-50 \mathrm{~mm}$ and $50-75 \mathrm{~mm}$ to determine whether the internal parts of the test walls were wet.

Samples of mortar collected from the walls were sent to the Geotechnical Laboratory at the Building and Road Research Institute (BRRI) of the Council for Scientific and Industrial Research 
352 (CSIR) in Kumasi, Ghana, where the moisture contents were determined in accordance with BS 3531377 (1990).

354 The moisture content (MC) was determined by the oven-dry method at $105^{\circ}$ to constant weight. The amount of moisture in the samples was determined and expressed as a percentage of its dry mass. Fifty (50) grams each of the mortar (in the SB 6 and CB 6) were put into moisture cans and the masses were measured $\left(\mathrm{M}_{1}\right)$. The samples were then oven dried and measured again $\left(\mathrm{M}_{2}\right)$. The moisture content was determined using the formular below:

$\mathrm{MC}=\frac{M 1-M 2}{M 2} \times 100 \%$
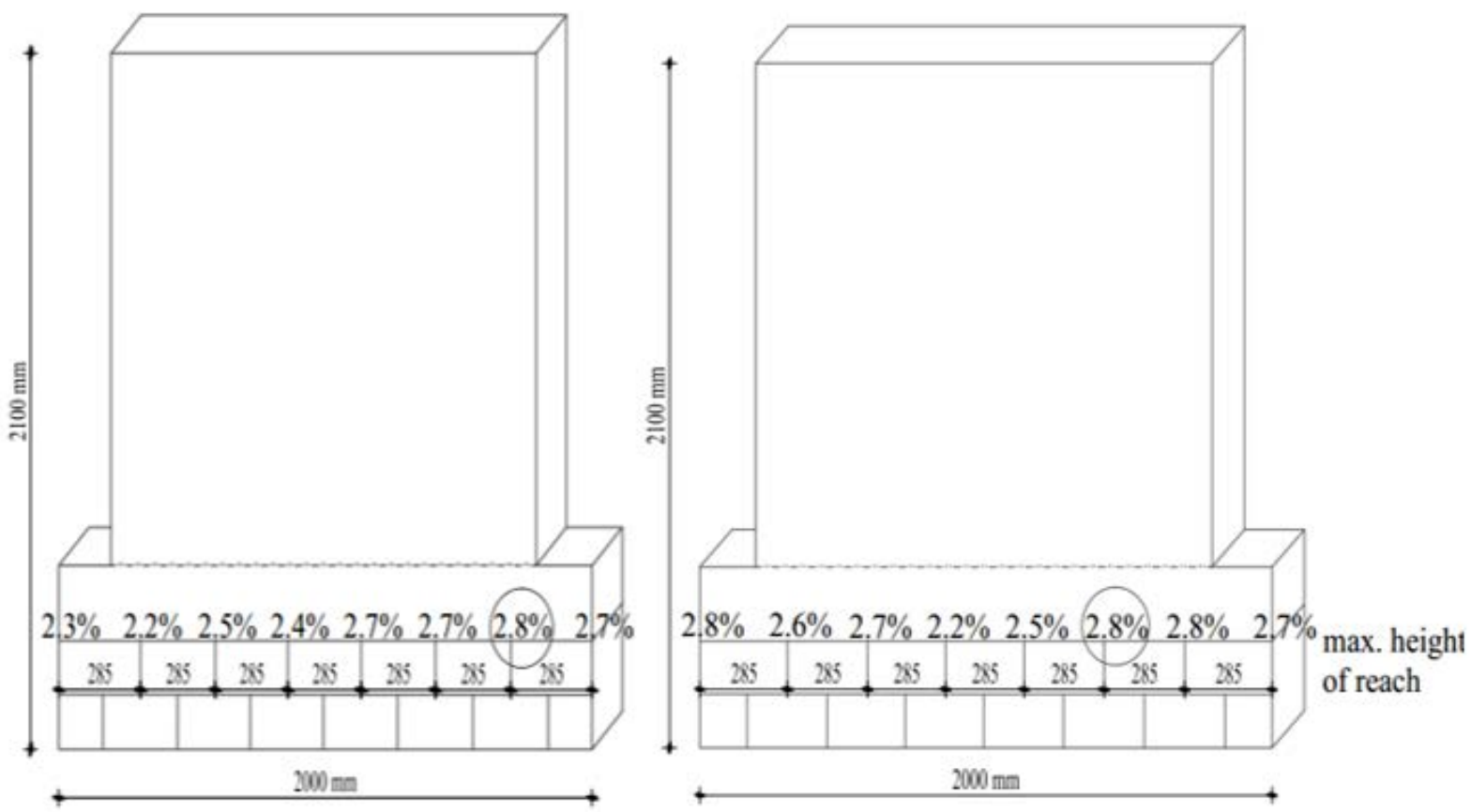

360 361

362

363

364 365

Fig 9 Schematic diagrams of the two walls with the various moisture contents as recorded by the moisture meter. (left-SB6 and right-CB6)

\subsection{Results and discussion}

The results obtained from monitoring the effectiveness of the mechanisms are presented to include the following:

\subsection{Visual observation}

One month after erecting the walls, a slowly progressing rising water front was visually observed. By the fifth month, the front had reached close to a third of the first course from ground level for the walls constructed with SB, and more than two thirds for that constructed with the CB. These initial observations were closely associated with the quality of the sandcrete blocks manufactured in the two cases. For instance, preliminary sorptivity test conducted on the two sets of sandcrete block samples ( $\mathrm{SB}$ and $\mathrm{CB}$ ) indicated that the those manufactured with the $\mathrm{CB}$ were more 
susceptible to water rise as compared to those made from SB. This indicate that the issue of quality control should really be taken into consideration during the manufacture of sandcrete blocks to be used in construction in Ghana.

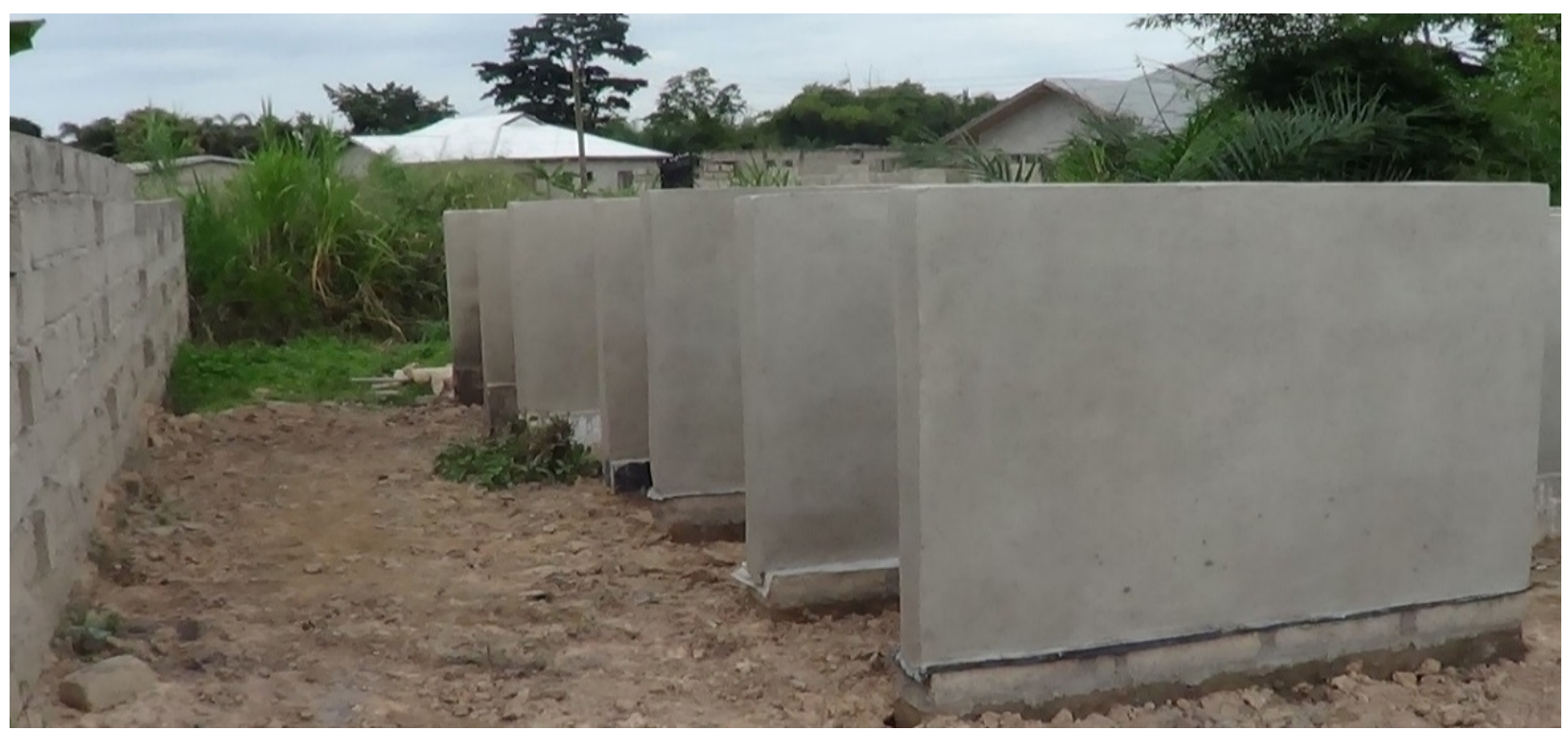

Fig 10a Photograph showing the damp front achieved by moisture in the walls constructed

\subsection{Height of rise of moisture in the walls}

The walls were further allowed to reach steady levels of saturation a little over five months after which the height of rise of the moisture levels were visually recorded. In this study much emphasis was placed on the ability of the water to rise and fall within the test walls constructed. This was very important because in addition to the aim the study was also conducted to replicate the scenario of rising damp in a normal ground condition, as opposed to that simulated in laboratories as has been conducted in several studies (Franzoni and Bandini, 2012; Rirsch and Zhang, 2010; Torres et al., 2010). The readings taken for the various measurements are presented in Tables 2a to 2c (indicated in the appendix). From the trend in Table 2, it can clearly be seen that during the rainy seasons, there was a general increase in the level of capillary rise of moisture. However, in the dry seasons, the capillary rise decreased. This clearly shows the movement of water to and fro within the walls. This scenario can well be explained based on the explanation given by Riley and Cotgrave (2005).

According to Riley and Cotgrave (2005), majority of construction materials are porous, and because they are always embedded in or in contact with the ground such materials encourage the migration of water from the ground through capillary action. If the water table of the ground surrounding the wall is very high, then such a condition can be achieved, clearly explaining why within the rainy season, the moisture rose higher in the current walls under investigation. 
Riley and Cotgrave (2005) further stated that if the ground is not saturated, the soil exerts a suction that opposes the upward pull of the water in the wall. As a result, when the water table falls, the height of the moisture in the walls will drop to a new level provided there is sufficient time for equilibrium to be achieved. This further shows why in the dry season, the water levels recorded in the walls were lower (Figure 10b). Each period of heavy rain on the ground at the base of the wall produces a temporary condition of saturation following which the water level in the wall rises again.
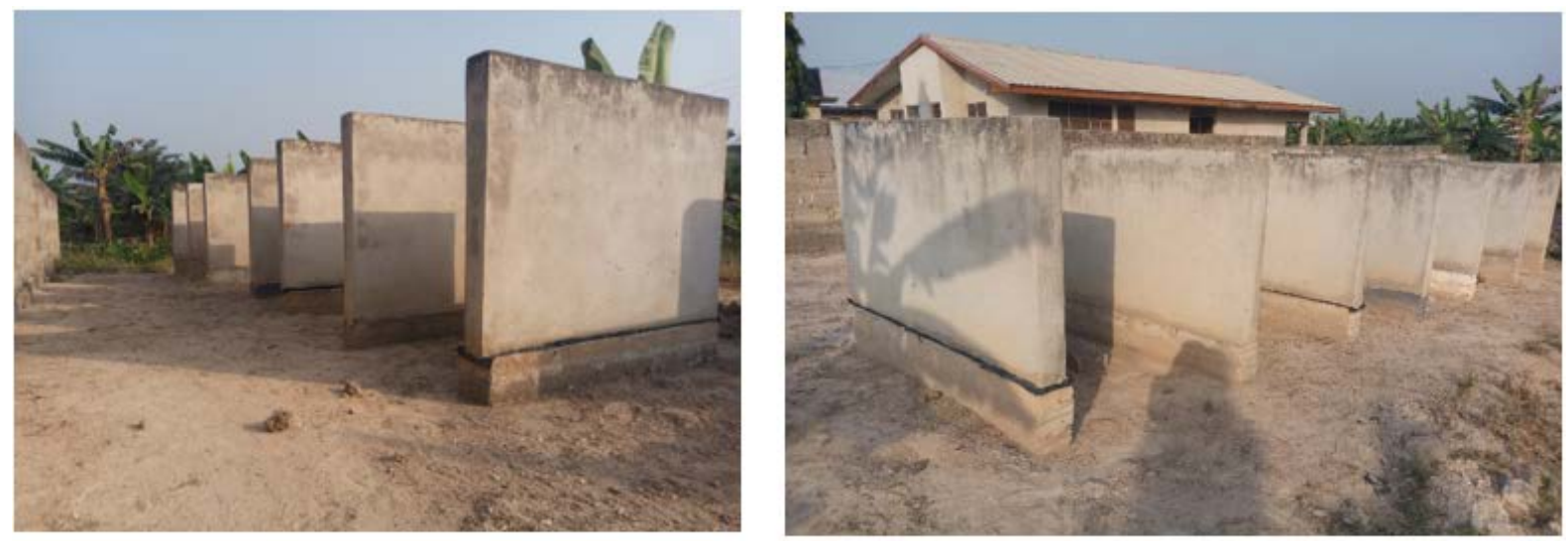

Fig 10b Photographs showing the conditions of the walls in the dry season

Tables 2a to 2c further shows that though water rose in the walls constructed with the SBs, the heights of rise was lower than that constructed with the CBs. The extent to which any wall will be affected by rising damp depends on the level of moisture in the ground, the features of the wall enabling or restricting evaporation from its surface, the porosity of the materials used to construct the walls, and the chemical composition of the migrating water (Riley and Cotgrave, 2005).

Figures 11a, 11b and 11c show the capillary rise of water recorded at various heights at the bases of the different walls. Only the values measured at the peak seasons (i.e. November for the rainy seasons and May for the dry seasons) have been presented in the figures. The peak seasons were chosen because it was found that during the peak of the rainy season, the water table rose, thereby increasing the amount of water in the ground and subsequently the increase in water in the walls (Figures 11a, 11b and 11c). During the peak of the dry seasons however the opposite happened (Figures 11a, 11b and 11c). All the other readings taken for the individual months are shown in Tables 2a, 2b and 2c attached as an Appendix. 


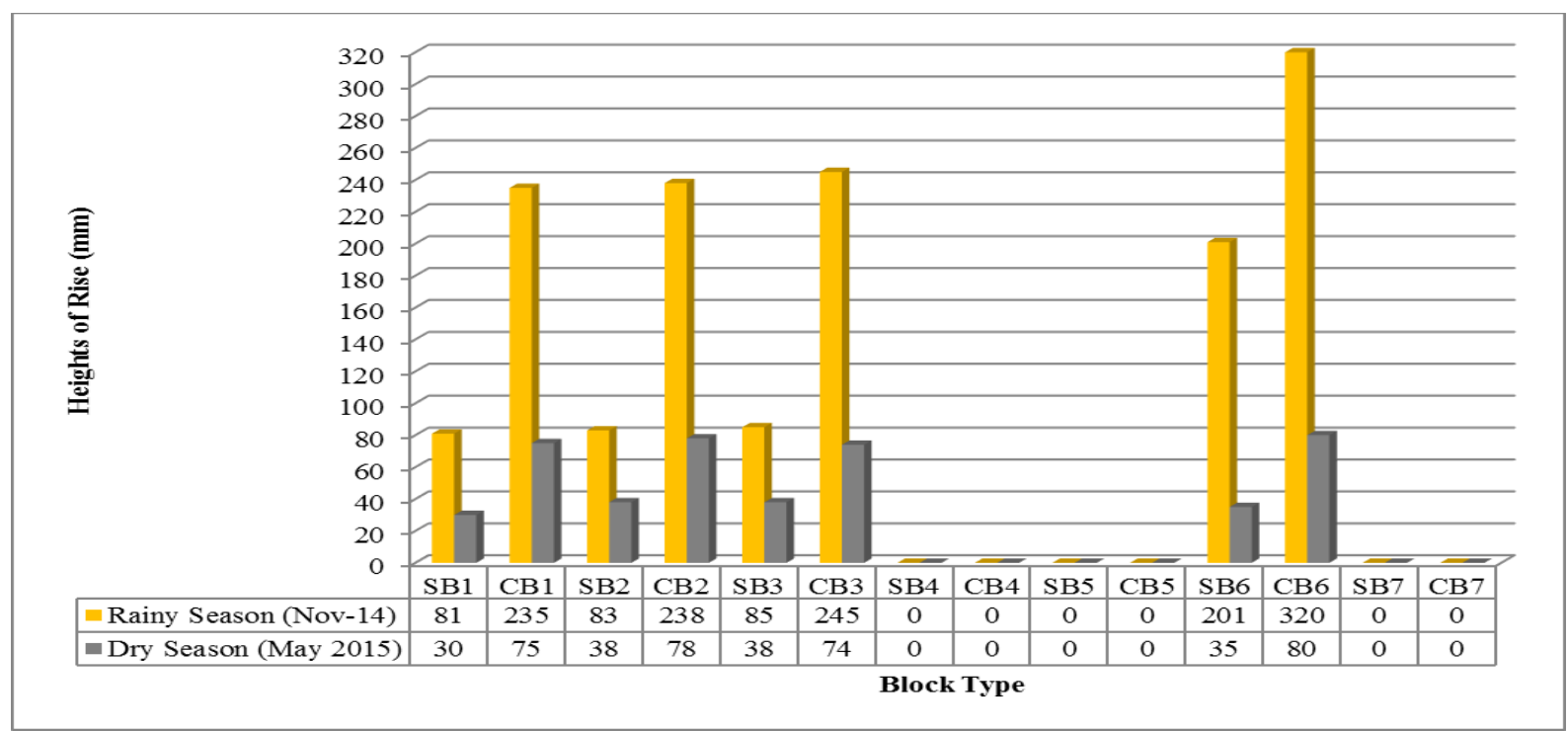

Fig 11a Capillary rise of water visually recorded at the peak of the seasons for 2014-2015

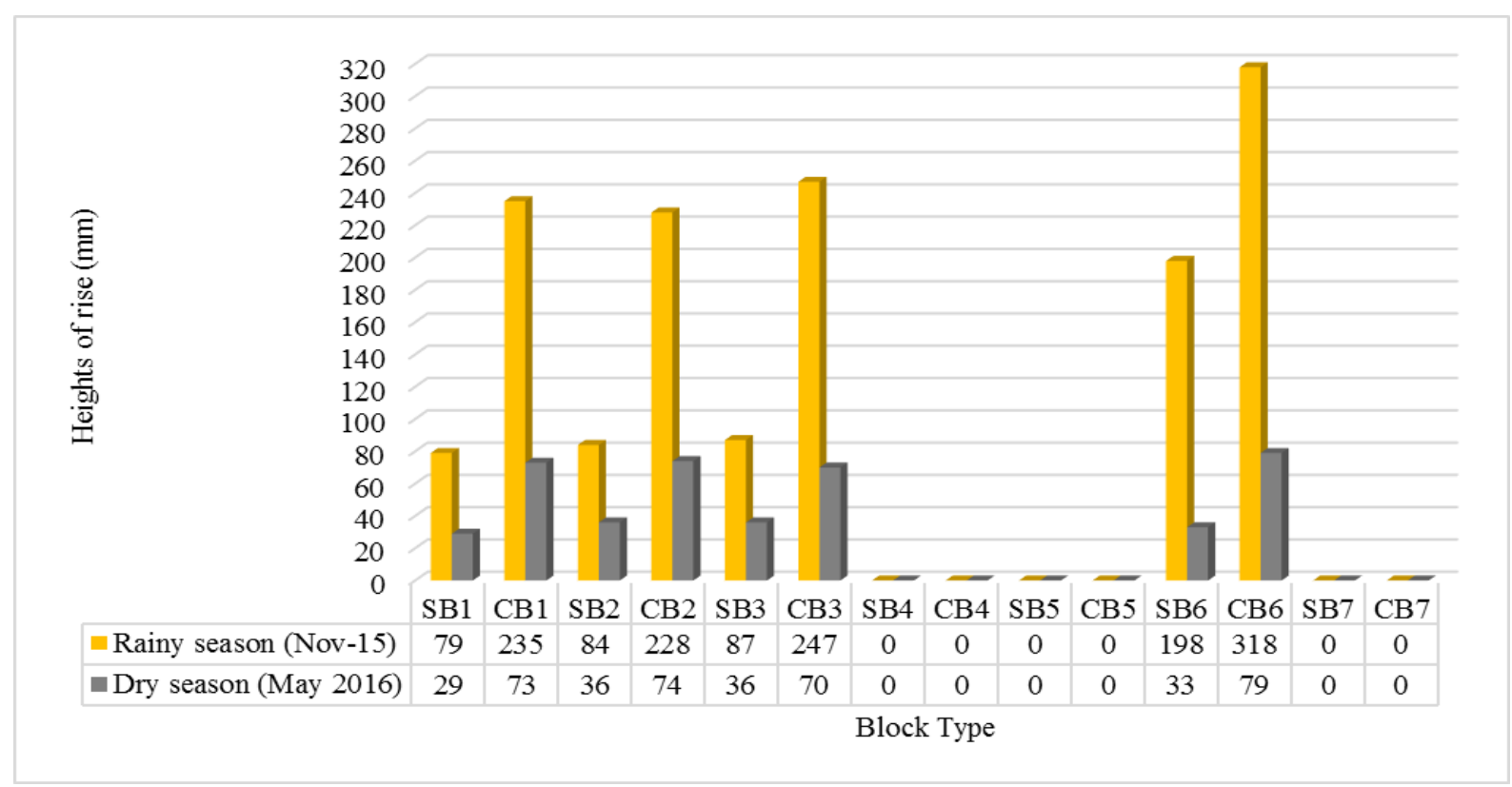

422 Fig 11b Capillary rise of water visually recorded at the peak of the seasons for 2015-2016 


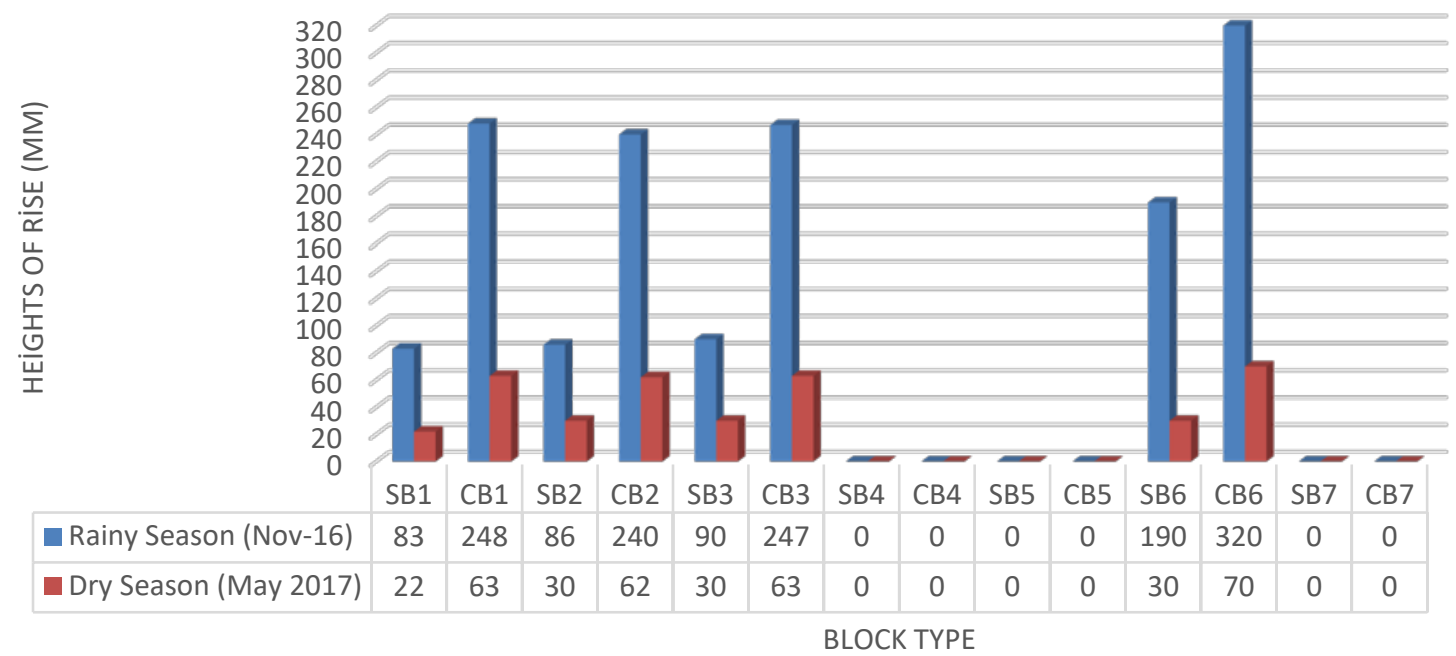

Fig 11c Capillary rise of water visually recorded at the peak of the seasons for 2016-2017

426

\subsection{Effectiveness of the mechanisms to prevent the capillary rise of water in the walls}

The effectiveness of the various treatment methods determined based on measurement of the capillary rise of water in the walls are discussed under the following sub-headings to include:

\subsubsection{Test walls (SB1and CB1; SB2 and CB2; SB3 and CB3) with polyethylene dpcs}

Though at the peak of the rainy seasons (Figure 12) the water levels rose higher, especially in the block walls manufactured with the CBs, the water could not go beyond the dpcs.

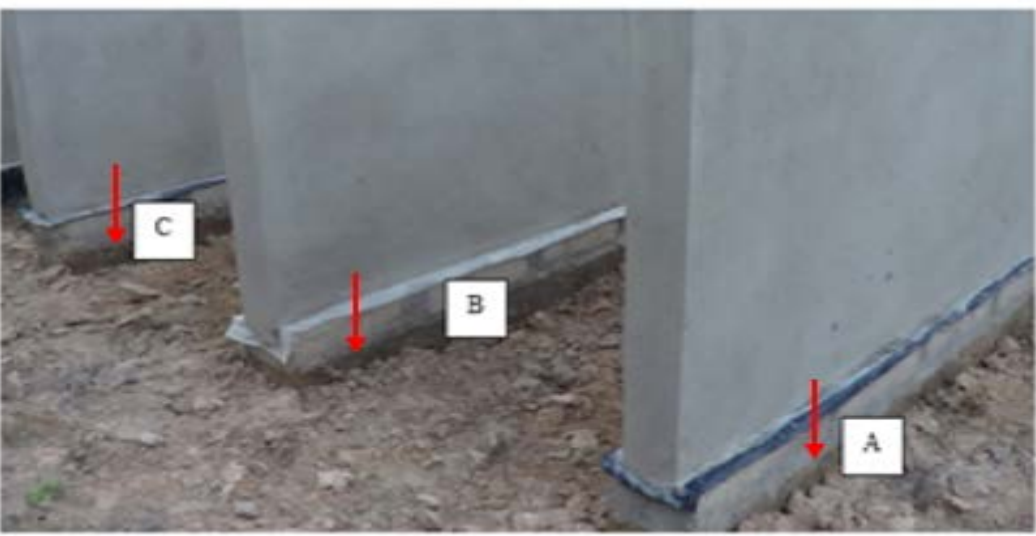

Fig 12 Water rise at the bases of the walls treated with three different DPCs - $0.15 \mathrm{~mm}$ thick (A), $0.12 \mathrm{~mm}$ thick (B) and $0.13 \mathrm{~mm}$ thick (C) 
441 This indicates that the dpcs acted as barriers that prevented the water from rising higher. 442 Comparing this scenario to that in SB 6 and CB 6 (Figure 14), there is the likelihood that water 443 would have risen higher in the walls had the dpcs not been in place. From Figure 12 it is clearly 444 evident that the bases that had not been treated had been soaked with water. The ability of the 445 water to rise in the walls depended on factors such as ground and soil conditions, environmental 446 factors, climatic factors, etc of the area.

447

448

449

450

451

452

453

454

455

456

457

458

459

460

461

\subsubsection{Test walls with the damp proof coatings}

Figures 13a and 13b show the conditions of the two sets of walls (SB 4, CB 4; SB 5, CB 5) treated with the damp proof coatings during the rainy and dry seasons. The monitoring revealed that 4 years into the treatment of the walls, the damp proof coatings ' $\mathrm{A}$ ' and ' $\mathrm{B}$ ' are working perfectively. Moisture content measurements with the PCE MMK1 moisture meter with deep probes showed no traces of water at the bases of the walls, and the inner parts were considerably dry. This is because the entire perimeters of the wall bases were completely covered with the coatings, which filled the pore spaces within the sandcrete blocks, making it difficult for water to rise and penetrate.
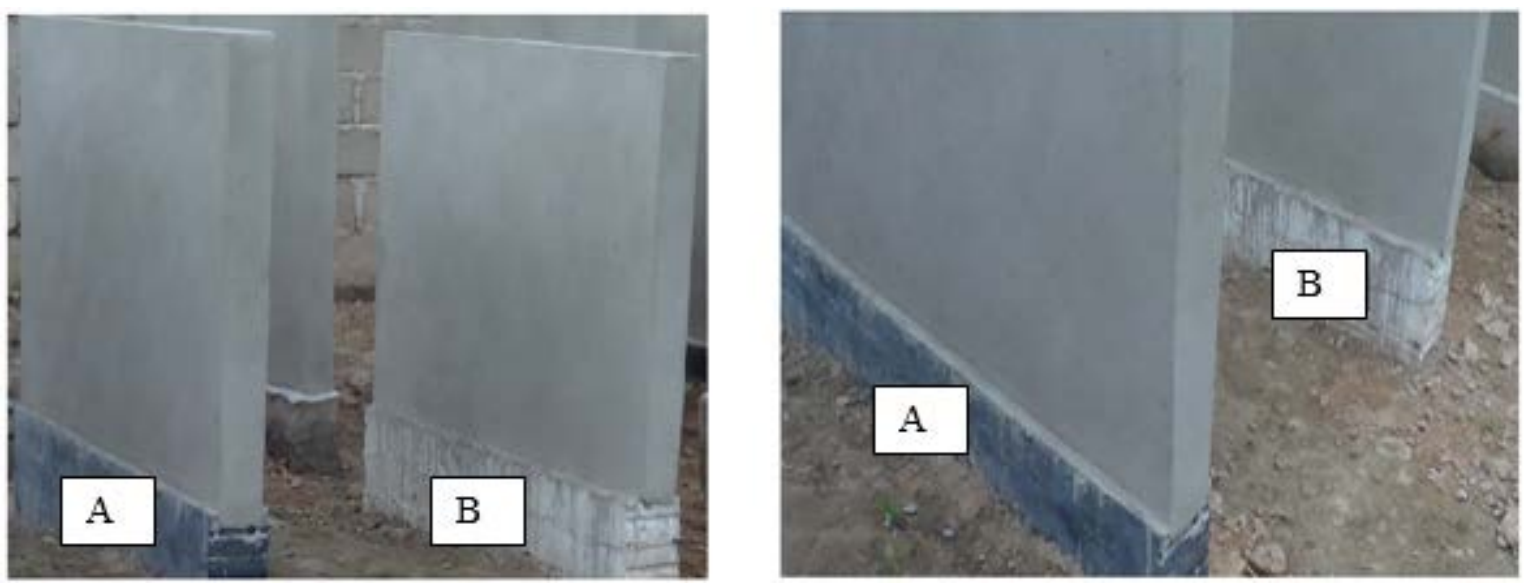

Fig 13a Photographs showing the conditions of the treated walls in the rainy season 

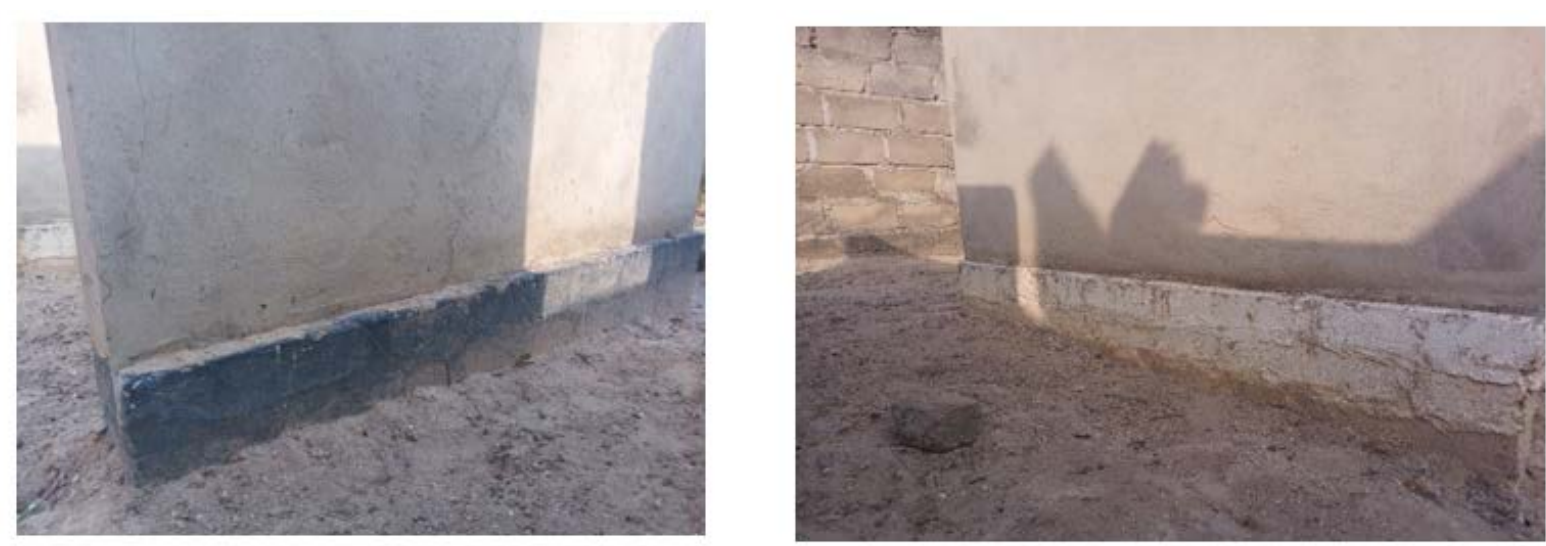

Fig 13b Photographs showing the conditions of the treated walls in the dry season

\subsubsection{Results from test walls with concrete bases}

Test wall 7 for the two sets of sandcrete blocks were constructed with dense concrete bases. After four years of monitoring the walls against the capillary rise of moisture, the findings revealed that the bases of the walls showed no traces of moisture rise or penetration. The concrete bases were very dense and did not permit the ingress of water by capillary action. Figure 14 is a photograph that shows the conditions of the walls for the two different constructions.
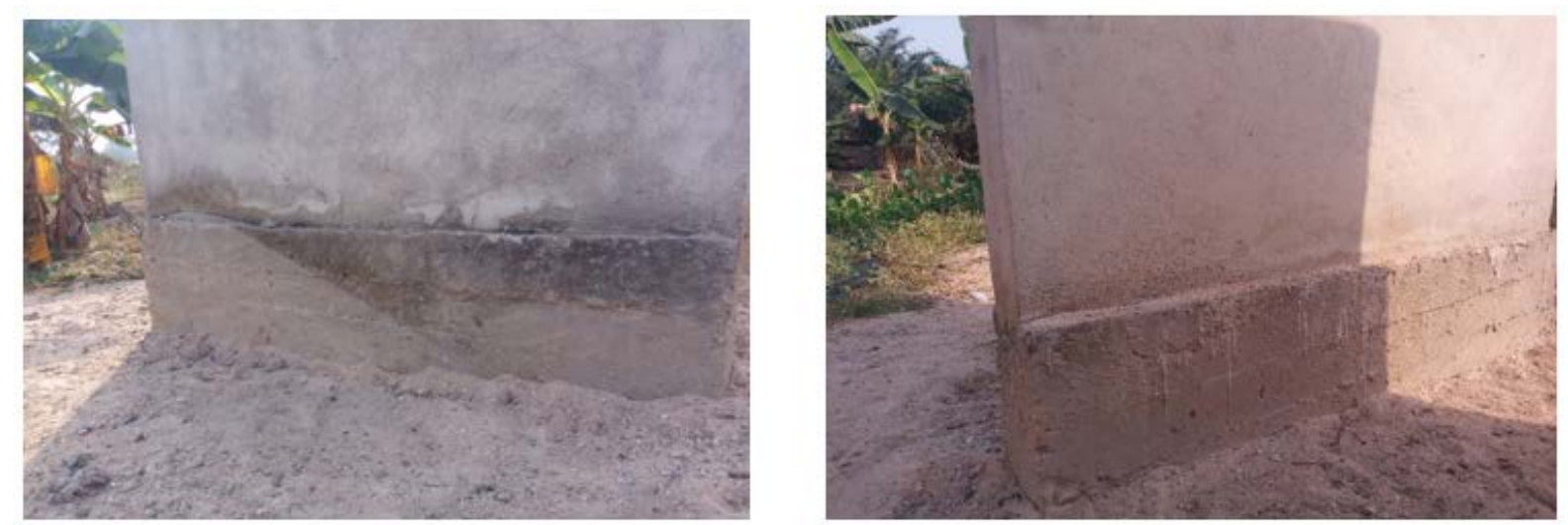

Fig 14 Photographs showing the conditions of the test walls with concrete bases

\subsection{Conditions of the control test walls (SB 6 and CB 6) without treatment mechanisms}

For the test walls that were untreated and used as controls, considerable amount of water could be observed in the walls during the rainy season. However, in the dry seasons the water levels decreased drastically because of a drop in the water table within the vicinity. It is worthy to note that as compared to the other walls with the control mechanisms, the water levels always rose past the dpc level. This is what makes these walls the controls because the effectiveness of the other mechanisms can easily be compared against them. For the four-year period of monitoring these control walls, this scenario has been occurring. 
To further demonstrate that the moisture was not only present on the surfaces of the walls but internally as well, mortar samples were obtained from the control test walls for laboratory testing during the rainy season in November 2016. The moisture contents were determined for the mortar samples obtained from Test walls 6 for both the SB and the CB. The results are shown in Tables 3a and $3 b$ respectively.
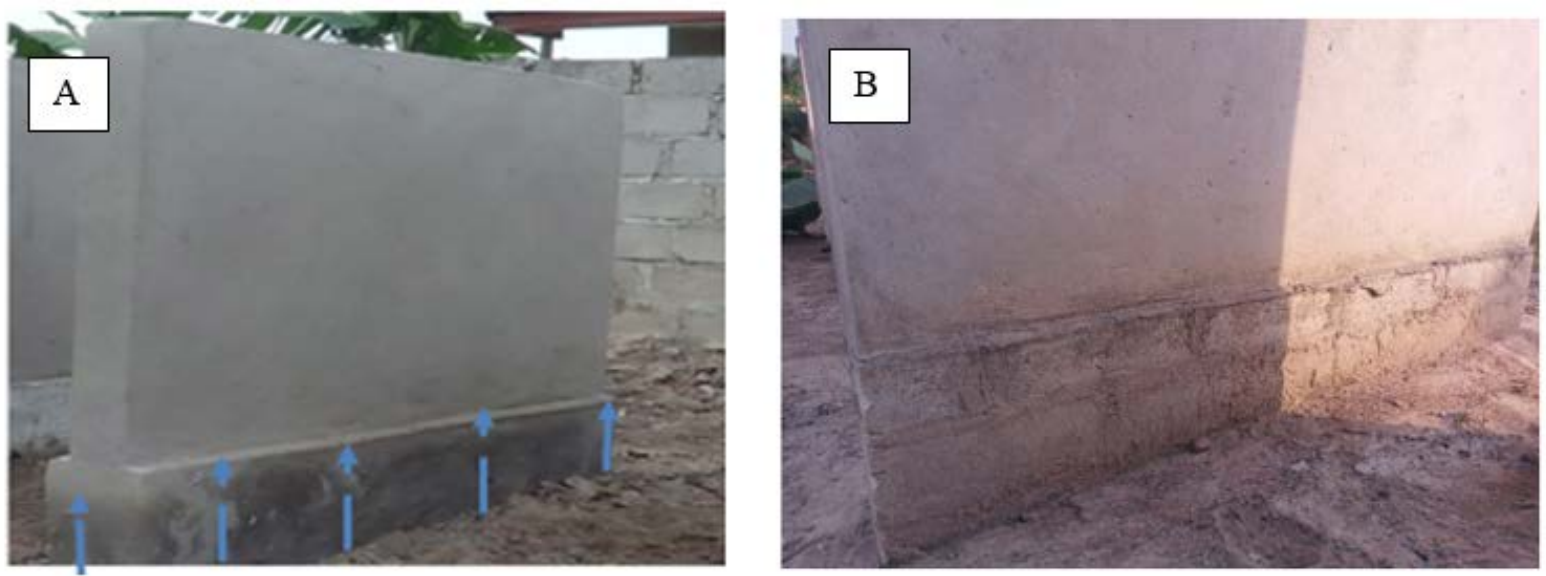

Fig 15 Photographs showing the presence (left) and absence (right) of water at the bases of the walls

Table 3a Moisture content of mortar samples collected at different depths in Test wall 6 (SB)

\begin{tabular}{|l|l|}
\hline DEPTH & \% MOISTURE CONTENT \\
\hline & Maximum height reached (201 mm for Test wall 6 manufactured with SB) \\
\hline $0-25 \mathrm{~mm}$ & 3.284 \\
\hline $25-50 \mathrm{~mm}$ & 3.404 \\
\hline $50-75 \mathrm{~mm}$ & 3.450 \\
\hline
\end{tabular}

Table 3b Moisture content of mortar samples collected at different depths in Test wall 6 (CB)

\begin{tabular}{|l|l|}
\hline DEPTH & \% MOISTURE CONTENT \\
\hline & Maximum height reached (320 mm for Test wall 6 manufactured with CB) \\
\hline $0-25 \mathrm{~mm}$ & 3.193 \\
\hline $25-50 \mathrm{~mm}$ & 3.609 \\
\hline $50-75 \mathrm{~mm}$ & 3.772 \\
\hline
\end{tabular}

The results show that the moisture contents varied with depths, that is, the deeper the mortar sample, the higher the moisture content and vice versa. This is a clear indication that the walls were sufficiently soaked with water. Hence, the moisture was not only present on the surfaces, but internally as well. 
99

\subsection{Parallel comparison of results with previously published laboratory results}

As stated earlier on in the introduction, the study of rising damp has received numerous attention worldwide. This sub-section compares the findings from the current study with some of the previously published findings from laboratory experiments.

In 1991 Aghamo et al. conducted a laboratory experimental study on how rising damp occurs in masonry. Twenty masonry walls (12 of which were made of Tufa blocks and 8 clay filled bricks) were constructed in tanks that were filled with water. To replicate a true rising damp scenario, the researchers kept the water level in the tank at constant rate using an overflow pipe. The researchers closely monitored the wall specimens, and after every two weeks, they poured water into the tank until it leaked out of the copper pipe (overflow). The water used to fill the tank was sourced from a water tank that was periodically supplied by a well that collects ground water. The researchers used this source of water to replicate water with salt characteristics like those in actual ground soil. After a year, the researchers visually observed water traces in some of the walls that resulted from the capillary rise of water from the tank. Between June 1992 and September 1993, the researchers subjected 10 out of the 20 walls to chemical dpcs, four untreated (to act as reference walls), and the others to mechanical dpcs. The findings from their study revealed the ability of water to rise up in the walls erected in the tanks, and further confirmed the validity of the proposed laboratory method to check the effectiveness of the proposed treatments.

This current study was a replication of the study of Aghamo et al. (1991), but with different material (i.e. sandcrete block wall) and with walls erected in actual ground conditions, not in the laboratory. Despite using a different material and actual ground setting, the findings also confirmed the ability of water to rise in masonry materials (in this case sandcrete blocks) when subjected to ground water. Similar to the effectiveness of the chemical dpcs presented in Aghamo et al. (1991) work, the damp proof coatings used in the current study also exhibited similar effectiveness as had been reported. This finding confirms the fact that water truly rise in buildings when they are subjected to the ground without any proper preventive measures in place. Similar laboratory studies that confirm this fact have also been reported by: Burkinshaw (2012) in the Lambeth Pier Test Walls; Torres and de Freitas (2007), who simulated rising damp in the laboratory and applied the wall base ventilation system to treat it; Hola et al. (2008) who also demonstrated the ability of water to rise by capillarity in brick walls through impedance tomography; Rirsch and Zhang (2010) who erected different walls on trays in a laboratory to simulate rising damp in masonry walls, and to show the importance of the properties of mortar in the capillary rise of water; among others.

The uniqueness of the current study lies in two things: the demonstration of the ability of water rise in a material (sandcrete block) different from other materials reported in the numerous literature reviewed; and the ability to demonstrate that rising damp truly exist through the construction of the walls in actual ground conditions. 


\subsection{Conclusion and recommendations}

542 The use of modern technology in building infrastructure has increased in recent years. Despite this

543

544

545

546

547

548

549

550

551

552

553

554

555

556

557

558

559

560

561

562

563

564

565

566

567

568

569

570

571

572

573

574

575

576

577

578

579 revolution, the industry is still battling one major issue, i.e. defects associated with building infrastructure. Defective building construction may not only affect the final cost of the product, but also the cost of maintenance of the product. It is therefore very important to ensure that as much as possible, all or most of the defects in buildings are eliminated right from the onset of construction. As a common building defect, rising damp has become a torn in the flesh of most construction professionals, as well as building occupants. This study was conducted to explore mechanisms that can be used to prevent rising damp in new buildings. Fourteen prototype test walls were constructed and different treatment mechanisms were applied. The test walls were constructed with sandcrete blocks manufactured to standard and commercial specifications. The test walls were monitored for four years against rising damp, followed by the close monitoring of the effectiveness of the treatment mechanisms. The monitoring of the walls was done based on the two climatic seasons in Ghana (rainy and dry seasons). From the findings it was evident that rising damp truly exists. This was confirmed by the constant increase and decrease in the height of the water levels in the walls during the rainy and dry seasons. The findings further revealed that although all the treatment mechanisms performed well within the four-year period, the walls treated with the damp proof coatings, together with those with the dense concrete bases performed better than those treated with the polyethylene dpcs. Despite this encouraging results, it should be noted that the application of epoxy coatings to materials may completely seal off all the pores within such materials, and this may intend lead to blistering, causing such coatings to fail. It is recommended that the walls to which the epoxy coatings have been applied be monitored for longer periods against such blistering, and effective measures put in place to prevent such. The study further recommends a future study to look at the economic and commercial impacts of the proposed preventive mechanisms. The safety of the mechanical interruptions (polyethylene dpc) in seismic conditions is also an issue worth noting and studying. Finally, it is recommended that simulation tests be performed to understand what is expected to occur in the long term. The results obtained from the simulation could assist in validating the conclusion. This will assist surveyors in advising clients on how they would achieve better value for their money, whilst they attain quality in the methods they use to prevent the problem.

\subsection{Implications}

Rising damp has been on the known among researchers worldwide for years now. However, there have been series of myths disapproving its existence in buildings in Ghana. This study has therefore proven to critics that rising damp is evident in walls and therefore closed that knowledge gap. This study bridges that gap as the constructed test walls offer insights into the potential for moisture to rise up in solid block walls from the ground. The proposed treatments mechanisms have also shed light on the effectiveness of some treatments applied to walls to prevent the capillary rise of water from the ground into the superstructure. The findings from this study 
provides knowledge on how basic construction principles could be used to prevent the problem of rising damp, especially, in the construction of new buildings. With the annual growth of housing stock increasing yearly in Ghana, the proposed treatment mechanisms if properly implemented, should devoid new trends of buildings of the problem of rising damp. This will provide adequate time for existing buildings with the problem to be studied and remedied. Rising damp may have taken its roots and position in existing buildings. However, if proper measures are put in place during the construction of new buildings, the problem could be prevented right at its source, with little work to be done in tackling it in existing buildings.

\section{References}

Adinkrah-Appiah, K., Adom-Asamoah, M. and Owusu Afrifa, R. (2015), “Reducing environmental degradation from construction activities: The use of recycled aggregates for construction in Ghana”, Journal of Civil Engineering and Architecture Research, Vol. 2 No.8, pp. 831-841.

African Development Bank (2013), “AfDB strategy for 2013-2022: At the centre of Africa’s transformation”, available at: http://www.afdb.org/en/documents/document/afdb-strategy-forfor-2013-2022-at-the-centre-ofoafricas-transformation-31420/ (accessed 23 July 2016).

African Development Bank (2018), “African Economic Outlook 2018”, available at: https://www.afdb.org/fileadmin/uploads/ (accessed 8 February 2018).

Aghemo, C., d'Ambrosio, F.R., Fato, I. and Alfano, G. (1993), "Rising dampness in masonry: Some experimental results”, Thermal Envelopes, Vol. 6, pp. 407-414.

Agyekum, K., Ayarkwa, J. and Koranteng, C. (2016), “Controlling rising damp in new buildings: Field trials of proposed treatment methods”, In Proceedings of International Conference on Infrastructure Development in Africa, Johannesburg, South Africa, pp. 447-466.

Agyekum, K., Ayarkwa, J. and Koranteng, C. (2014), "Holistic diagnosis of rising damp and salt attack in two residential buildings in Kumasi, Ghana”, Journal of Construction Engineering, Vol. 2014, pp. 1-13.

Agyekum, K., Ayarkwa, J., Koranteng C. and Adinyira, E. (2013), "Preliminary assessment of dampness in walls of residential buildings in four climatic zones in Ghana”, Journal of Sustainable Development, Vol 6 No. 9, pp. 51-61.

Baiden, B.K. and Tuuli, M.M. (2004), "Impact of quality control practices in sandcrete blocks production”, Journal of Architectural Engineering, Vol. 10 No. 2, pp. 53-60.

British Standard Code, 1200 (1976), "Specification for building sands from Natural sources”, British Standard Institutes, London, UK. 
615

616

617

618

619

620

621

622

623

624

625

626

627

628

629

630

631

632

633

634

635

636

637

638

639

640

641

642

643

644

645

646

647

648

British Standard Code, BS 2028 (1975), “Precast concrete blocks”, British Standard Institute, London, UK.

British Standard Code, BS 6515 (1984), "Specification for polyethylene damp-proof courses for masonry”, British Standard Institute, London, UK.

British Standards Institute, BSI, (1974), “'Specification for clay bricks and blocks.”’ BS 3921, London.

Burkinshaw, R. (2012), “Rising damp: Part 1, Case Study Examples and the Lambeth Pier Test: How to Isolate Ground-Sourced Rising Damp by the 'Burkinshaw Test Method”, Journal of Building Survey, Appraisal and Valuation, Vol 1 No. 1, pp. 1-15.

Burkinshaw, R. and Parrett, M. (2004), Diagnosing damp, RICS BOOK, Coventry, UK.

Falchi, L., Slanzi, D., Balliana, E., Driussi, G. and Zendri, E. (2018), "Rising damp in historical buildings: A Venetian perspective”, Building and Environment, Vol. 131, pp. 117-127.

Franzoni, E. (2018), “State-of-the-art on methods for reducing rising damp in masonry”, Journal of Cultural Heritage, Vol. 31, supplement, pp. S3-S9.

Franzoni, E. (2014), “Rising damp removal from historical masonries: A still open challenge”, Construction and Building Materials, Vol. 54, pp. 123-136.

Franzoni, E., Bandini, S. and Graziani, G. (2014), "Rising moisture, salts and electrokinetic effects in ancient masonries: From laboratory testing to on-site monitoring”, Journal of Cultural Heritage, Vol. 15 No. 2, pp. 112-120.

Franzoni E. and Bandini, S. (2012), "Spontaneous electrical effects in masonry affected by capillary water rise: the role of salts”, Construction and Building Materials, Vol. 35, pp. 642646.

Franzoni, E. and Sassoni, E. (2011), "Correlation between microstructural characteristics and weight loss of natural stones exposed to simulated acid rain”, Sci Total Environ, Vol. 412-413, pp. 278-85.

Ghana Statistical Service, GSS, (2014), “2010 population and housing census”, available at: http://www.statsghana.gov.gh (accessed 3 March 2018). 
Hola, J., Matkowski, Z., Schabowicz, K., Sikora, J. and Wojtowicz, S. (2008), "New method of investigation of rising damp in brick walls by means of impedance tomography", $17^{\text {th }}$ World Conference on non-destructive testing, 25-28 October 2008, Shanghai, China.

Kesse, G.O. (1985), The Mineral and Rock Resources of Ghana. In: Balkema A.A., Rotterdam, the Netherlands.

Lewis, T.D. (1959), General specification for building works, Ministry of Works and Housing Publics Works Division, The Government Printer, Accra, Ghana.

Lubelli, B., van Hees, R.P.J. and Bolhuis, J. (2018), "Effectiveness of methods against rising damp in buildings: Results from the EMERISDA project”, Journal of Cultural Heritage, Vol. 315, pp. 515-522.

Lubelli, B.,van Hees, R.P.J and Hacquebord, A. (2013), "Experimental study of the distribution of chemical products against rising damp in substrates with different water saturation degrees", Construction and Building Materials, pp. Vol. 40, pp. 891-898.

Melada, J., Gargano, M., Veronese, I. and Ludwig, N. (2018), “Does electro-osmosis work in moisture damage prevention? Applicability of infrared-based methods to verify water distribution under electric fields, Journal of Cultural Heritage, Vol. 31, Supplement, pp. S38S45.

Neville, A.M. (1996), Properties of concrete, $4^{\text {th }}$ edn, Longman Group Ltd, London, UK.

Riley, M. and Cotgrave, A. (2005), “Dampness in Buildings”, Division of Sustainable Development. Available at: http://folders.nottingham.edu.cn, (accessed 5 April 2016).

Rirsch, E., MacMullen. J. and Zhang, Z. (2011), "Evaluation of mortar samples obtained from UK houses treated for rising damp”, Construction and Building Materials, Vol. 25, pp. 28452850.

Rirsch, E. and Zhang, Z. (2010), "Rising damp in masonry walls and the importance of mortar properties”, Construction and Building Materials, Vol. 24, 1815-1820,

Torre, I. (2018), “New techniques for treating rising damp in historic buildings: Wall base ventilation, Journal of Cultural Heritage, Vol. 31, Supplement, pp. S60-S70.

Torres, I. and de Freitas, V.P. (2010), “The influence of the thickness of the walls and their properties on the treatment of rising damp in historic buildings", Construction and Building Materials, Vol. 24, pp. 1331-1339. 
689 Van Hees, R.P.J., Lubelli, B. and Hacquebord, A. (2018), “New test methods to verify the 690 performance of chemical injections to deal with rising damp”, Journal of Cultural Heritage, Vol.

691 31, Supplement, pp. S52-S59.

692

693 Vanhellemont, Y., Bolhuis, J., de Bouw, M., Dubois, S., Lubelli, B., Miedema, L. and van Hees, 694 R. (2018), “Are electrokinetic methods suitable for the treatment of rising damp?”, Journal of 695 Cultural Heritage, Vol. 31, Supplement, pp. S23-S29.

696

697

698

699

700

701

702 


\begin{tabular}{|c|c|c|c|c|c|c|c|c|c|c|c|}
\hline \multirow{18}{*}{ 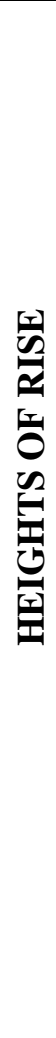 } & \multirow{2}{*}{$\begin{array}{l}\text { BLOCK } \\
\text { TYPE }\end{array}$} & \multicolumn{4}{|c|}{ RAINY SEASON } & \multicolumn{6}{|c|}{ DRY SEASON } \\
\hline & & $\begin{array}{c}\text { August } \\
2014\end{array}$ & $\begin{array}{l}\text { September } \\
2014\end{array}$ & $\begin{array}{c}\text { October } \\
2014\end{array}$ & $\begin{array}{l}\text { November } \\
2014\end{array}$ & $\begin{array}{c}\text { December } \\
2014 \\
\end{array}$ & $\begin{array}{c}\text { January } \\
2015\end{array}$ & $\begin{array}{l}\text { February } \\
2015\end{array}$ & $\begin{array}{l}\text { March } \\
2015\end{array}$ & $\begin{array}{l}\text { April } \\
2015\end{array}$ & $\begin{array}{l}\text { May } \\
2015\end{array}$ \\
\hline & SB1 & $70 \mathrm{~mm}$ & $75 \mathrm{~mm}$ & $79 \mathrm{~mm}$ & $81 \mathrm{~mm}$ & $55 \mathrm{~mm}$ & $40 \mathrm{~mm}$ & $40 \mathrm{~mm}$ & $40 \mathrm{~mm}$ & $38 \mathrm{~mm}$ & $30 \mathrm{~mm}$ \\
\hline & CB1 & $215 \mathrm{~mm}$ & $228 \mathrm{~mm}$ & $230 \mathrm{~mm}$ & $235 \mathrm{~mm}$ & $150 \mathrm{~mm}$ & $95 \mathrm{~mm}$ & $82 \mathrm{~mm}$ & $80 \mathrm{~mm}$ & $80 \mathrm{~mm}$ & $75 \mathrm{~mm}$ \\
\hline & SB2 & $73 \mathrm{~mm}$ & $78 \mathrm{~mm}$ & $80 \mathrm{~mm}$ & $83 \mathrm{~mm}$ & $64 \mathrm{~mm}$ & $43 \mathrm{~mm}$ & $43 \mathrm{~mm}$ & $41 \mathrm{~mm}$ & $40 \mathrm{~mm}$ & $38 \mathrm{~mm}$ \\
\hline & CB2 & $220 \mathrm{~mm}$ & $230 \mathrm{~mm}$ & $235 \mathrm{~mm}$ & $238 \mathrm{~mm}$ & $162 \mathrm{~mm}$ & $100 \mathrm{~mm}$ & $85 \mathrm{~mm}$ & $83 \mathrm{~mm}$ & $80 \mathrm{~mm}$ & $78 \mathrm{~mm}$ \\
\hline & SB3 & $75 \mathrm{~mm}$ & $80 \mathrm{~mm}$ & $82 \mathrm{~mm}$ & $85 \mathrm{~mm}$ & $64 \mathrm{~mm}$ & $45 \mathrm{~mm}$ & $45 \mathrm{~mm}$ & $43 \mathrm{~mm}$ & $40 \mathrm{~mm}$ & $38 \mathrm{~mm}$ \\
\hline & CB3 & $235 \mathrm{~mm}$ & $240 \mathrm{~mm}$ & $243 \mathrm{~mm}$ & $245 \mathrm{~mm}$ & $164 \mathrm{~mm}$ & $98 \mathrm{~mm}$ & $85 \mathrm{~mm}$ & $80 \mathrm{~mm}$ & $78 \mathrm{~mm}$ & $74 \mathrm{~mm}$ \\
\hline & SB4 & $0 \mathrm{~mm}$ & $0 \mathrm{~mm}$ & $0 \mathrm{~mm}$ & $0 \mathrm{~mm}$ & $0 \mathrm{~mm}$ & $0 \mathrm{~mm}$ & $0 \mathrm{~mm}$ & $0 \mathrm{~mm}$ & $0 \mathrm{~mm}$ & $0 \mathrm{~mm}$ \\
\hline & CB4 & $0 \mathrm{~mm}$ & $0 \mathrm{~mm}$ & $0 \mathrm{~mm}$ & $0 \mathrm{~mm}$ & $0 \mathrm{~mm}$ & $0 \mathrm{~mm}$ & $0 \mathrm{~mm}$ & $0 \mathrm{~mm}$ & $0 \mathrm{~mm}$ & $0 \mathrm{~mm}$ \\
\hline & SB 5 & $0 \mathrm{~mm}$ & $0 \mathrm{~mm}$ & $0 \mathrm{~mm}$ & $0 \mathrm{~mm}$ & $0 \mathrm{~mm}$ & $0 \mathrm{~mm}$ & $0 \mathrm{~mm}$ & $0 \mathrm{~mm}$ & $0 \mathrm{~mm}$ & $0 \mathrm{~mm}$ \\
\hline & CB 5 & $0 \mathrm{~mm}$ & $0 \mathrm{~mm}$ & $0 \mathrm{~mm}$ & $0 \mathrm{~mm}$ & $0 \mathrm{~mm}$ & $0 \mathrm{~mm}$ & $0 \mathrm{~mm}$ & $0 \mathrm{~mm}$ & $0 \mathrm{~mm}$ & $0 \mathrm{~mm}$ \\
\hline & SB 6 & $72 \mathrm{~mm}$ & $75 \mathrm{~mm}$ & $78 \mathrm{~mm}$ & $201 \mathrm{~mm}$ & $78 \mathrm{~mm}$ & $65 \mathrm{~mm}$ & $50 \mathrm{~mm}$ & $45 \mathrm{~mm}$ & $42 \mathrm{~mm}$ & $35 \mathrm{~mm}$ \\
\hline & CB 6 & $215 \mathrm{~mm}$ & $250 \mathrm{~mm}$ & $265 \mathrm{~mm}$ & $320 \mathrm{~mm}$ & $195 \mathrm{~mm}$ & $150 \mathrm{~mm}$ & $95 \mathrm{~mm}$ & $90 \mathrm{~mm}$ & $86 \mathrm{~mm}$ & $80 \mathrm{~mm}$ \\
\hline & SB7 & $100 \mathrm{~mm}$ & $80 \mathrm{~mm}$ & $50 \mathrm{~mm}$ & $0 \mathrm{~mm}$ & $0 \mathrm{~mm}$ & $0 \mathrm{~mm}$ & $0 \mathrm{~mm}$ & $0 \mathrm{~mm}$ & $0 \mathrm{~mm}$ & $0 \mathrm{~mm}$ \\
\hline & CB7 & $112 \mathrm{~mm}$ & $85 \mathrm{~mm}$ & $55 \mathrm{~mm}$ & $0 \mathrm{~mm}$ & $0 \mathrm{~mm}$ & $0 \mathrm{~mm}$ & $0 \mathrm{~mm}$ & $0 \mathrm{~mm}$ & $0 \mathrm{~mm}$ & $0 \mathrm{~mm}$ \\
\hline & \multirow{2}{*}{\multicolumn{4}{|c|}{$\begin{array}{l}\text { Moisture content increased with month in the } \\
\text { rainy season }\end{array}$}} & $\begin{array}{l}\text { PEAK } \\
\text { VALUES } \\
\text { Moisture }\end{array}$ & \multicolumn{5}{|c|}{ Moisture content decreased with month in the dry season } & \multirow{2}{*}{$\begin{array}{l}\text { Moisture } \\
\text { content } \\
\text { recorded } \\
\text { is } \\
\text { minimum }\end{array}$} \\
\hline & & & & & $\begin{array}{l}\text { content } \\
\text { recorded is } \\
\text { maximum }\end{array}$ & & & & & & \\
\hline
\end{tabular}


Table 2b Heights of rise of moisture in the walls from August 2015 to May 2016

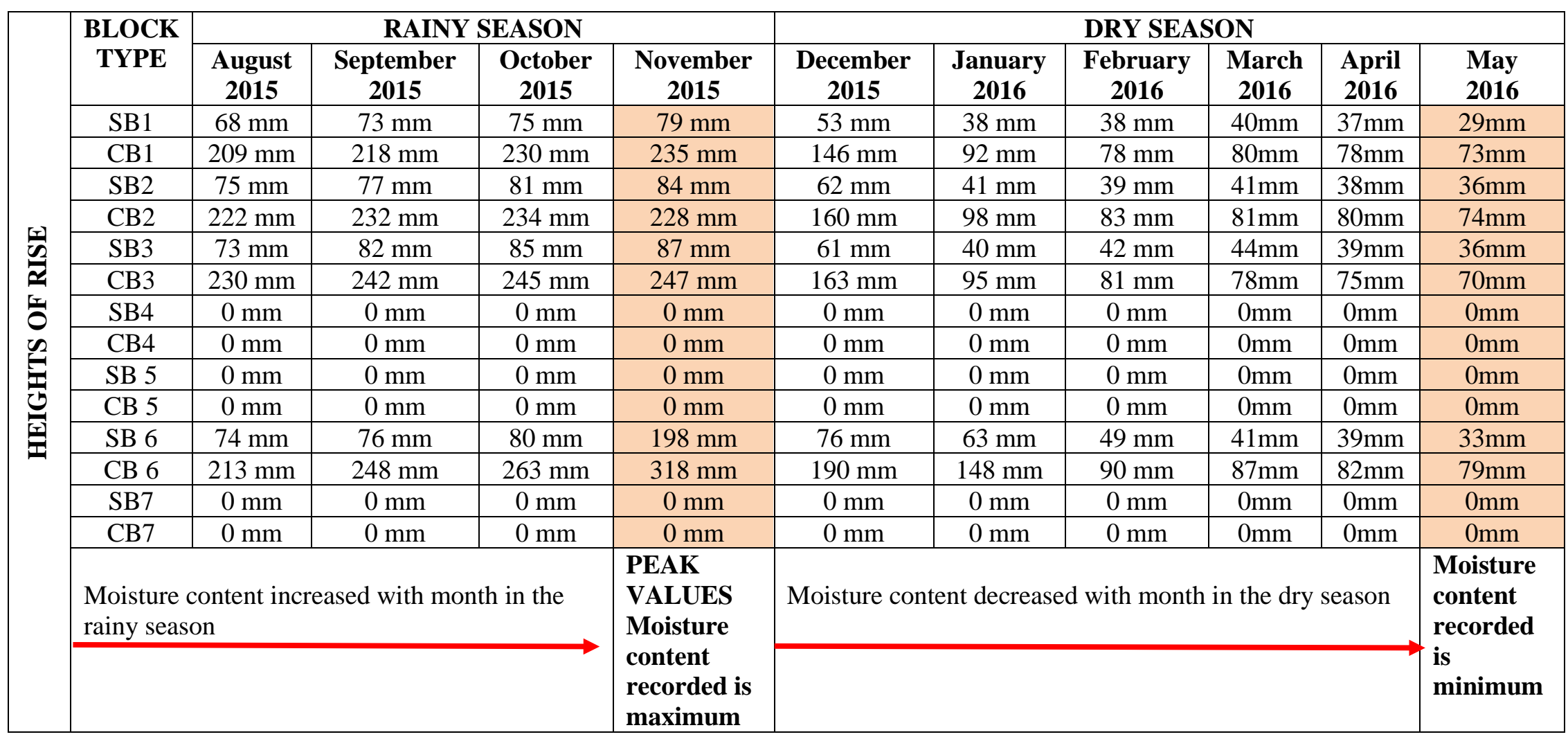


Table 2c Heights of rise of moisture in the walls from August 2016 to May 2017

\begin{tabular}{|c|c|c|c|c|c|c|c|c|c|c|c|}
\hline \multirow{18}{*}{ 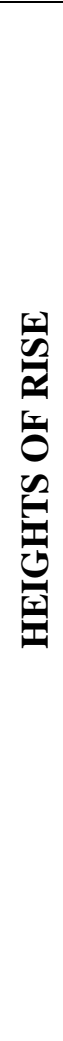 } & \multirow{2}{*}{$\begin{array}{l}\text { BLOCK } \\
\text { TYPE }\end{array}$} & \multicolumn{4}{|c|}{ RAINY SEASON } & \multicolumn{6}{|c|}{ DRY SEASON } \\
\hline & & $\begin{array}{l}\text { August } \\
2016 \\
\end{array}$ & $\begin{array}{c}\text { September } \\
2016 \\
\end{array}$ & $\begin{array}{c}\text { October } \\
2016 \\
\end{array}$ & $\begin{array}{c}\text { November } \\
2016 \\
\end{array}$ & $\begin{array}{c}\text { December } \\
2016 \\
\end{array}$ & $\begin{array}{c}\text { January } \\
2017\end{array}$ & $\begin{array}{c}\text { February } \\
2017\end{array}$ & $\begin{array}{c}\text { March } \\
2017\end{array}$ & $\begin{array}{c}\text { April } \\
2017\end{array}$ & $\begin{array}{l}\text { May } \\
2017\end{array}$ \\
\hline & SB1 & $72 \mathrm{~mm}$ & $74 \mathrm{~mm}$ & $75 \mathrm{~mm}$ & $83 \mathrm{~mm}$ & $48 \mathrm{~mm}$ & $35 \mathrm{~mm}$ & $32 \mathrm{~mm}$ & $37 \mathrm{~mm}$ & $35 \mathrm{~mm}$ & $22 \mathrm{~mm}$ \\
\hline & CB1 & $220 \mathrm{~mm}$ & $238 \mathrm{~mm}$ & $240 \mathrm{~mm}$ & $248 \mathrm{~mm}$ & $140 \mathrm{~mm}$ & $90 \mathrm{~mm}$ & $73 \mathrm{~mm}$ & $74 \mathrm{~mm}$ & $71 \mathrm{~mm}$ & $63 \mathrm{~mm}$ \\
\hline & SB2 & $78 \mathrm{~mm}$ & $82 \mathrm{~mm}$ & $84 \mathrm{~mm}$ & $86 \mathrm{~mm}$ & $60 \mathrm{~mm}$ & $38 \mathrm{~mm}$ & $35 \mathrm{~mm}$ & $40 \mathrm{~mm}$ & $34 \mathrm{~mm}$ & $30 \mathrm{~mm}$ \\
\hline & CB2 & $231 \mathrm{~mm}$ & $234 \mathrm{~mm}$ & $236 \mathrm{~mm}$ & $240 \mathrm{~mm}$ & $156 \mathrm{~mm}$ & $97 \mathrm{~mm}$ & $80 \mathrm{~mm}$ & $73 \mathrm{~mm}$ & $75 \mathrm{~mm}$ & $62 \mathrm{~mm}$ \\
\hline & SB3 & $75 \mathrm{~mm}$ & $81 \mathrm{~mm}$ & $87 \mathrm{~mm}$ & $90 \mathrm{~mm}$ & $63 \mathrm{~mm}$ & $42 \mathrm{~mm}$ & $38 \mathrm{~mm}$ & $40 \mathrm{~mm}$ & $33 \mathrm{~mm}$ & $30 \mathrm{~mm}$ \\
\hline & CB3 & $232 \mathrm{~mm}$ & $242 \mathrm{~mm}$ & $245 \mathrm{~mm}$ & $247 \mathrm{~mm}$ & $160 \mathrm{~mm}$ & $93 \mathrm{~mm}$ & $79 \mathrm{~mm}$ & $74 \mathrm{~mm}$ & $70 \mathrm{~mm}$ & $63 \mathrm{~mm}$ \\
\hline & SB4 & $0 \mathrm{~mm}$ & $0 \mathrm{~mm}$ & $0 \mathrm{~mm}$ & $0 \mathrm{~mm}$ & $0 \mathrm{~mm}$ & $0 \mathrm{~mm}$ & $0 \mathrm{~mm}$ & $0 \mathrm{~mm}$ & $0 \mathrm{~mm}$ & $0 \mathrm{~mm}$ \\
\hline & CB4 & $0 \mathrm{~mm}$ & $0 \mathrm{~mm}$ & $0 \mathrm{~mm}$ & $0 \mathrm{~mm}$ & $0 \mathrm{~mm}$ & $0 \mathrm{~mm}$ & $0 \mathrm{~mm}$ & $0 \mathrm{~mm}$ & $0 \mathrm{~mm}$ & $0 \mathrm{~mm}$ \\
\hline & SB 5 & $0 \mathrm{~mm}$ & $0 \mathrm{~mm}$ & $0 \mathrm{~mm}$ & $0 \mathrm{~mm}$ & $0 \mathrm{~mm}$ & $0 \mathrm{~mm}$ & $0 \mathrm{~mm}$ & $0 \mathrm{~mm}$ & $0 \mathrm{~mm}$ & $0 \mathrm{~mm}$ \\
\hline & CB 5 & $0 \mathrm{~mm}$ & $0 \mathrm{~mm}$ & $0 \mathrm{~mm}$ & $0 \mathrm{~mm}$ & $0 \mathrm{~mm}$ & $0 \mathrm{~mm}$ & $0 \mathrm{~mm}$ & $0 \mathrm{~mm}$ & $0 \mathrm{~mm}$ & $0 \mathrm{~mm}$ \\
\hline & SB 6 & 72 mm & $74 \mathrm{~mm}$ & $82 \mathrm{~mm}$ & $190 \mathrm{~mm}$ & $73 \mathrm{~mm}$ & $60 \mathrm{~mm}$ & $45 \mathrm{~mm}$ & $39 \mathrm{~mm}$ & $36 \mathrm{~mm}$ & $30 \mathrm{~mm}$ \\
\hline & CB 6 & $225 \mathrm{~mm}$ & $233 \mathrm{~mm}$ & $245 \mathrm{~mm}$ & $320 \mathrm{~mm}$ & $192 \mathrm{~mm}$ & $137 \mathrm{~mm}$ & $85 \mathrm{~mm}$ & $82 \mathrm{~mm}$ & $78 \mathrm{~mm}$ & $70 \mathrm{~mm}$ \\
\hline & SB7 & $0 \mathrm{~mm}$ & $0 \mathrm{~mm}$ & $0 \mathrm{~mm}$ & $0 \mathrm{~mm}$ & $0 \mathrm{~mm}$ & $0 \mathrm{~mm}$ & $0 \mathrm{~mm}$ & $0 \mathrm{~mm}$ & $0 \mathrm{~mm}$ & $0 \mathrm{~mm}$ \\
\hline & CB7 & $0 \mathrm{~mm}$ & $0 \mathrm{~mm}$ & $0 \mathrm{~mm}$ & $0 \mathrm{~mm}$ & $0 \mathrm{~mm}$ & $0 \mathrm{~mm}$ & $0 \mathrm{~mm}$ & $0 \mathrm{~mm}$ & $0 \mathrm{~mm}$ & \begin{tabular}{l}
\multicolumn{1}{c}{$0 \mathrm{~mm}$} \\
Moisture \\
content \\
recorded \\
is \\
minimum
\end{tabular} \\
\hline & \multirow{2}{*}{\multicolumn{4}{|c|}{$\begin{array}{l}\text { Moisture content increased with month in the } \\
\text { rainy season }\end{array}$}} & \multirow{2}{*}{$\begin{array}{l}\text { PEAK } \\
\text { VALUES } \\
\text { Moisture } \\
\text { content } \\
\text { recorded is } \\
\text { maximum }\end{array}$} & \multicolumn{5}{|c|}{ Moisture content decreased with month in the dry season } & \multirow{2}{*}{$\begin{array}{l}\text { Moisture } \\
\text { content } \\
\text { recorded } \\
\text { is } \\
\text { minimum }\end{array}$} \\
\hline & & & & & & & & & & & \\
\hline
\end{tabular}

